\title{
Re-examining the debt-growth nexus: \\ A grouped fixed-effect approach
}

Instituto

Complutense

de Análisis

Económico

\author{
Marta Gómez-Puig \\ Department of Economics \\ Universitat de Barcelona \\ Spain
}

Simón Sosvilla-Rivero

Complutense Institute for Economic Analysis

Universidad Complutense de Madrid

Spain

Inmaculada Martínez-Zarzoso

Faculty of Economic Sciences

University of Göttingen

Germany

\section{Abstract}

This paper uses panel data for 116 countries over the period 1995-2016 to investigate the heterogeneity of the debt-growth nexus across countries and the factors underlying it. In the first step, the grouped fixed effects (GFE) estimator proposed by Bonhomme and Manresa (2015) is used to classify countries into groups, with group membership being endogenously determined. In the second step, a multinomial logit model is used to explore the drivers of the heterogeneity detected, among them the quality of institutions, the composition of debt-funded public expenditure, the relative public and private indebtedness, and the maturity of debt. Finally, the underlying factors explaining the time-varying impact of public debt on growth in the country groups identified is also investigated.

Keywords Public debt, economic growth, heterogeneity, grouped fixedeffects, debt-growth link, panel data, multinomial logit regression

JEL Classification $\quad$ C23, F33, H63, O47, O52

\section{Working Paper no 1921}

July, 2019 
"Que no, que no,

que el pensamiento

no puede tomar asiento,

que el pensamiento es estar

siempre de paso, de paso, de paso"

Luis Eduardo Aute

\section{Introduction}

The nexus between public debt and economic growth, a traditional focus of study for economists, has recently undergone a notable revival fuelled by the substantial deterioration of public finances in many economies after the global financial and economic crisis of 2008-2009. According to Fitch Ratings, government debt hit \$66 trillion through the end of 2018 , or about $80 \%$ of global GDP ${ }^{1}$.

A decade after the global financial crisis, government debt-to-GDP ratios are still above their pre-crisis levels. These high levels of public sector indebtedness involve risks especially for advanced and emerging economies. On the one hand, as global monetary conditions tighten, the debt burden may grow and rollover risks increase. On the other hand, the debt burden limits the ability of governments to provide support to the economy in the event of a downturn or a financial crisis. Although there is widespread agreement about the potentially adverse consequences of unparalleled levels of public debt for economies' growth, few macroeconomic policy debates have generated as much controversy as the austerity argument [see Guajardo et al. (2014), Jordà and Taylor (2016) or Alesina et al. (2019a, 2019b)], especially in the current context of waning momentum in the major economies.

From an empirical point of view, the existing literature has grouped studies into two strands (see Mitze and Matz, 2015). The "first generation" strand includes the works by Reinhart and Rogoff (2010), Pattillo et al., (2011), Lof and Malinen (2014) and Woo and Kumar (2015), among others. This strand focused mainly on the nonlinear effects in the

\footnotetext{
${ }^{1}$ The Global Debt Database published by the International Monetary Fund (IMF) shows similar figures. According to the IMF, global debt has reached an all-time high of $\$ 184$ trillion in nominal terms, the equivalent of $225 \%$ of GDP in 2017. However, of the global total of $\$ 184$ trillion in debt at the end of 2017 , close to two-thirds was nonfinancial private debt and the remaining one-third was public debt.
} 
debt-growth relationship and predicted an inverted U-shape relationship between the two variables (debt begins to harm economic growth when the debt-to-GDP ratio exceeds a certain threshold $-90 \%$, according to the seminal paper by Reinhart and Rogoff (2010)). The "second generation" strand goes beyond the nonlinearities in the relationship and focuses instead on the heterogeneity of debt-growth nexuses across countries [Ghosh $e t$ al. (2013), Pescatori et al. (2014), Edberhardt and Presbitero (2015), Markus and Rainer (2016), Chudik et al. (2017), Chiu and Lee (2017) or Gómez-Puig and Sosvilla-Rivero (2017, 2018a)]. The studies in the second strand acknowledge that the effects of public debt on growth may vary depending on country-specific macroeconomic, financial, and institutional variables.

In this context, the current paper belongs to the above-mentioned "second generation" of studies and aims to contribute to the existing literature in three respects. First, the originality of the analysis arises from the adoption of a recently developed method from the panel time series literature: the grouped fixed effects (GFE) estimator proposed by Bonhomme and Manresa (2015). To the best of our knowledge, this is the first paper to apply the GFE methodology to examine whether the debt-growth relationship differs across groups of countries, with the pattern of heterogeneity being endogenously determined by the data ${ }^{2}$. Second, the GFE methodology will also be used to examine whether the impact of debt on economic growth changes over time by estimating groupspecific time-varying coefficients. Although it is also widely agreed that heterogeneities in the debt-growth relationship occur not only across countries but also over time, this issue has hardly been studied by the literature (the exceptions include Yang and Su (2018) and Gómez-Puig and Sosvilla-Rivero (2018b)) ${ }^{3}$. The third contribution of this paper is to analyse the drivers of the heterogeneous impact of debt on economic growth. To this end, we first explore the determinants of group membership, making use of a multinomial logit regression model to assess the role of five types of variables ${ }^{4}$ : (1) the quality of institutions,

\footnotetext{
${ }^{2}$ The GFE estimator takes into account the possibility that different countries experience distinct dynamics in the debtgrowth relationship, with the group-specific time patterns and individual group membership being left unrestricted and estimated from the data. Furthermore, the GFE estimator arguably deals better with endogeneity due to unobserved heterogeneity.

${ }^{3}$ Yang and Su (2018) extend the regression kink model of Hansen (2017) and find clear evidence that the debt-to-GDP threshold is time-varying and state-dependent (however, a limitation of their work is that the choice of debt-threshold determinants is arbitrary). While Gómez-Puig and Sosvilla-Rivero (2018b) empirically investigate the short and the long run impact of public debt on economic growth by applying the Autoregressive Distributed Lag (ARDL) bounds testing approach.

${ }^{4}$ In a recent paper, Fatás et al. (2019) point out that treating debt as a black box and imposing the restriction that any given level of debt has the same consequence on economic growth, regardless of its structure, is simplistic. In particular, they state that one of the reasons why it is difficult to identify common patterns and to pin down the causal effect of debt on growth is that not all debts are equal, and factors such as (1) what the debt was used for, (2) who holds government debt, (3) its currency composition, and (4) its maturity are key elements that can affect fiscal vulnerabilities and the possible reactions of government and private agents to future changes in debt. We tried to find data for the four variables, but
} 
(2) the composition of public expenditure that is funded with debt, (3) relative public indebtedness, (4) relative private indebtedness, and (5) the maturity of debt ${ }^{5}$. We then analyse the role of these variables in explaining the time-varying impact of public debt on growth in the country groups identified.

This paper aims to fill these gaps in the literature by focusing on a sample of 116 countries (advanced, emerging and developing countries) over the period 1995-2016. The main results show that the relationship between public debt and growth varies across countries. In particular, the GFE estimator endogenously splits the sample into seven groups of countries that have dissimilar time patterns and a different estimated impact of a debt change on economic growth (ranging between -0.43 and -0.031). When analysing the heterogeneous time-varying impact of public debt on growth, our results indicate that the debt-growth relationship is crucially mitigated by the quality of a country's institutions and intensified by the level of both public and private indebtedness and the maturity of debt. The type of expenditure that is funded with debt also influences that relationship (negatively in the case of unproductive spending, and positively in the case of productive spending).

The rest of the paper is organized as follows. Section 2 presents the rationale for our empirical approach on the basis of the results of some preliminary descriptive analyses. Section 3 introduces the analytical framework. Section 4 describes the data used in the analysis. The econometric methodology is explained in Section 5. Empirical results are presented in Section 6, while Section 7 explores the determinants of group membership and the time-varying impact of public debt on growth. Finally, some concluding remarks and policy implications are offered in Section 8.

\section{Descriptive analysis}

In what follows, we provide some descriptive analyses highlighting the cross-country heterogeneity in the evolution of sovereign debt-to-GDP ratio in the 116 countries in our sample (see Appendix 1) over the period 1995-2016. Figure 1 shows the evolution of the average debt ratio in the three groups of countries into which the sample can be split,

obtained data only for the first (what the debt was used for) and the fourth (debt maturity) factors mentioned. Nevertheless, we have also included variables that proxy the quality of the institutions and the relative ratio of both private and public debt.

${ }_{5}$ As a proxy for the maturity of debt, we use short-term debt, expressed as a percentage of total external debt. 
following the International Monetary Fund (IMF) classification: advanced economies (AE), emerging market economies (EM), and low income developing countries (LIDC).

[Insert Figure 1 here]

We can observe that, from the outbreak of the global financial crisis (2008-09) until the end of the sample period in 2016, on average, global general government debt has risen by over $20 \%$ of GDP in advanced economies and by around 13\% of GDP in emerging markets, reaching a post-war high [see Bredenkamp et al., 2019 and Yared (2019)], whilst in lowincome developing countries (with only a few exceptions) new debt accumulation was contained during the crisis, thanks largely to the debt relief efforts of the late-1990s and early $2000 s^{6}$ (see Eichengreen et al., 2019) and did not experience an increase until 2012 (on average, $14 \%$ of GDP). These increases have given rise to average public debt-to-GDP ratios of around $75 \%, 54 \%$, and $56 \%$ in advanced economies, emerging markets and developing countries respectively at the end of 2016.

However, as public debt increases are far from being homogeneous within the three groups of countries, the debt-to-GDP ratios are highly dispersed in the different groups over the sample period. More specifically, despite their relatively moderate average values at the end of 2016, debt-to-GDP ratios registered values above 100\% in eight advanced economies and above $90 \%$ in three. Moreover, two emerging market and four low-income developing countries were also above $100 \%$.

Japan registered the highest government debt (not only in our sample, but also in the world) at 236\% of its GDP in 2016 (although, notably, Japan is also one of the world's largest economies and its share of public debt held by non-residents is traditionally very low - around $5-7 \%$ - which reduces its vulnerability). It is followed by Greece, which is still recovering from the effects of its economic crisis and subsequent bailout, at $183 \%$. It is noticeable that five euro area countries also registered ratios above or close to $100 \%$ at the end of 2016: Italy, Portugal, Belgium, Spain and France, with figures of 132\%, 130\%, 106\%, 99\% and 97\% respectively. Finally, several Caribbean and African countries also had high national debts at the end of the sample period, including Barbados (149\%), Jamaica (114\%), Belize (96\%), Republic of Congo (129\%), Cape Verde (128\%), Mauritania (100\%), Sudan (100\%) and Egypt (97\%).

\footnotetext{
${ }^{6}$ The Heavily Indebted Poor Countries (HIPC) initiative and the associated Multilateral Debt Relief Initiative (MDRI) explain these figures since recipient countries were required to establish a track-record of strong policy performance under IMF and World Bank supported programs before receiving large write-downs of both official bilateral and multilateral debt.
} 
Of the world's major economic powers, the United States registered the highest national debt at 107\% of its GDP in 2016. China, the world's second-largest economy and home to the world's largest population, had a public debt ratio of just 44\% of its GDP at the end of $2016^{7}$. Germany, Europe's largest economy, also had a relatively low sovereign debt ratio at $68 \%$. Among the 116 countries in our sample, at the other end of the scale, Estonia registered the lowest sovereign-debt-to-GDP ratio in 2016 (9\%), followed by three subSaharan African countries: Botswana (16\%), Congo Democratic Republic (19\%) and Nigeria (20\%).

All in all, the above figures indicate that the evolution of the public ratio of indebtedness presents very different patterns - not only across the 116 countries in our sample, but also within the three groups into which the sample is divided according to the IMF incomebased classification. This suggests that the use of the GFE methodology, which leaves group membership unrestricted rather than imposing it ex-ante, may represent a more useful tool for capturing those heterogeneities ${ }^{8}$. Moreover, they also provide a good reason for examining whether the differences in the relationship between debt and economic growth depend on factors others than per capita income, such as the institutional environment, the composition of debt-funded public expenditure, the relative ratio of private and public indebtedness, or debt maturity.

\section{Analytical framework}

Following Gómez-Puig and Sosvilla-Rivero (2017 and 2018a), the initial empirical specification is derived from the neoclassical growth model of Solow augmented with public debt, where the growth rate of real per capita GDP for a given country $i$ in time $t$ $\left(g_{t i}\right)$ is given by:

\footnotetext{
7 However, it is noticeable that China alone accounts for almost three-quarters of the increase in global private nonfinancial debt since the onset of the Global Financial Crisis, which represents over $200 \%$ of its GDP (see Bredenkamp et al., 2019)

${ }^{8}$ Gómez-Puig and Sosvilla-Rivero (2017 and 2018a) examined the heterogeneity in the public debt-economic growth nexus in EMU countries by means of time-series techniques. In principle, in those papers they are able to analyse each country separately by allowing complete individual heterogeneity, but this approach is not entirely practical, for several reasons: (1) individual estimations may be rather inefficient since they do not make use of cross-section information and (2) examining countries separately fails to capture any common patterns. On the other hand, much of the previous literature relies on panel data techniques and obtains an average relationship for a given group of countries. Therefore, since it is very important not only to impose some structure on individual heterogeneity but also to allow for different relationships within the sample, the grouped fixed effect (GFE) estimator seems well suited for the purposes of this paper.
} 


$$
g_{i t}=\alpha+\gamma y_{i t-1}+\sum_{j=1}^{n} \delta_{i j} X_{i j t}+\beta d_{i t}+\varepsilon_{i t}
$$

where $y_{i t-1}$ is the logarithm of initial real per capita GDP (to capture the "catch-up effect" or conditional convergence of the economy to its steady state), $X_{i j t}(j=1, \ldots, n)$ is a set of control variables, $d_{t i}$ is the public debt-to-GDP ratio, and $\varepsilon_{i t}$ denotes the error term.

Regarding $X_{i t}$, we consider a set of explanatory variables that have been shown to be consistently associated with growth in the literature': population growth rate as a percentage $\left(P O P G R_{i t}\right)$; the ratio of gross capital formation to GDP $\left(G C F_{i t}\right)$; life expectancy at birth, a proxy for the level of human capital $\left(H K_{i t}\right)^{10}$; openness to trade, measured by the sum of exports and imports over GDP $\left(O P E N_{i t}\right)$; and the GDP deflator inflation rate, a measure of macroeconomic instability and uncertainty $\left(I N F_{i t}\right)$.

In the economic growth literature, the rate of growth of labour used in the production process and the accumulation of physical capital (investment) are the key determinants of growth (Solow (1956) or Frankel (1962)). Therefore, population growth $\left(P O P G R_{t}\right)$ and the ratio of gross fixed capital formation to real GDP $\left(G C F_{t}\right)$ are used to proxy country size and the rate of labour growth and the accumulation of the physical capital stock respectively.

A proxy of human capital $\left(H K_{t}\right)$ is included to reflect the notion that countries with an abundance of human capital are more likely to be able to attract investors, absorb ideas from the rest of the world, and engage in innovation activities (Grossman and Helpman, 1991) Trade openness $\left(O P E N_{t}\right)$ is posited to boost productivity through transfers of knowledge and efficiency gains (Seghezza and Baldwin, 2008). Finally, with regard to the inflation rate $\left(I N F_{t}\right)$, it has been argued that inflation is a good macroeconomic indicator of how the government manages the economy [see Fischer (1993) or Barro (2003), among other authors] and that low inflation brings about economic efficiency because, through the price mechanism, economies are able to allocate scarce resources to their best economic use (World Bank, 1990).

\footnotetext{
9 See Aghion and Howitt (2009) for a comprehensive account of the most important contributions and debates on growth.

${ }_{10}$ This proxy is also used by Sachs and Warner (1997).
} 


\section{Data}

We use annual data for 116 countries (advanced economies, emerging market economies and low-income developing countries) over the period 1995-2016 (see Appendix 1).

To maintain as much homogeneity as possible for a sample of 116 countries over the course of two decades, we use the World Bank's World Development Indicators as our primary source. We then strengthen our data with the use of supplementary information from the International Monetary Fund (International Financial Statistics and World Economic Outlook, October 2018). As mentioned above, we first use per capita GDP at 2010 market prices, population growth rate, the ratio of gross capital formation to GDP, an index of human capital, openness to trade and GDP deflator inflation to examine the impact of debt on economic growth. The precise definitions and sources of the variables are presented in Appendix 2. In the second step, we make use of variables that measure the quality of institutions, the composition of public expenditure, the relative ratio of both public and private indebtedness, and debt maturity as potential drivers of the relationship in the different groups of countries found.

With regard to the variables that measure the quality of institutions, in this paper we rely on the definition of economic institutions proposed by Acemoglu et al. (2005b) where economic institutions are identified with the structure of property rights and access to economic resources. Thus, good economic institutions are ones that provide security of property rights and relatively equal access to economic resources to a broad cross-section of society. However, measuring the quality of institutions is a challenging task. It is common practice in the literature to measure it in terms of perceptions, which may not necessarily reflect the quality of the law but rather the actual workings of the economy. So, in this paper, to capture differences in the quality of country governance, we adopt a comprehensive composite index, the World Bank's Worldwide Governance Indicator (WGI), which offers better time-variate characteristics than other governance measures. The WGI index covers six broad dimensions of governance for over 200 countries since 1996, and summarizes views on the quality of country governance provided by a number of survey organizations, non-governmental organizations, commercial business information providers, and public sector organizations worldwide. It follows the methodology of Kaufmann et al. (2010) and is published annually by the World Bank. The six governance indicators it contains are: (1) voice and accountability, (2) political stability and absence of violence, (3) government effectiveness, (4) regulatory quality, (5) rule of law, and (6) control 
of corruption. This paper focuses on the average of the last four of these indicators ${ }^{11}$, which captures the quality of economic and administrative institutions (the definition of each of the four indicators included in our average measure is presented in Appendix 3). In particular, these indicators try to capture how the economic structure is able to deliver a level-playing field for all economic actors, ensure that rent extraction and waste of resources is limited, and provide sound economic incentives for encouraging people to invest, innovate, save, solve problems of collective actions and provide public goods. Therefore, in each year (following Chong and Gradstein (2007) and Beltratti and Stulz (2012)), we take the simple average of the four components of the WGI presented in Appendix 3 for each country. We then rescale this raw score so that it lies between zero and one by subtracting the minimum score from it and dividing the result by the maximum score minus the minimum score (this variable is named "government quality indicator" $\left(G Q I_{t}\right)$ in our analysis).

Data regarding private debt $\left(P R D E B T_{t}\right)$ have been drawn from the Global Debt Database. This database offers the total gross debt of the (private and public) nonfinancial sector for an unbalanced panel of 190 countries (see Mbaye et al., 2018) and for the 116 countries of our sample we have selected the variable total private debt as a percentage of GDP. This variable is calculated as the sum of two components ${ }^{12}$ : (1) bank loans to domestic households and nonfinancial corporations, drawn from the IMF's Standardized Reporting Forms (SRFs) and International Financial Statistics (IFS) and (2) the outstanding stock of debt securities issued (on the domestic and international markets) by non-financial corporations, calculated based on securities issuance data from Dealogic database ${ }^{13}$. Then, as explained in Appendix 3, much as the World Bank classifies countries by income (see Fantom and Serajuddi, 2016), we have classified them as low indebted, lower middle indebted, upper middle indebted, and high indebted, the cut-off points between each of the groups being the first, the second and the third quartiles. To this end, we use yearly data to create two dummy variables representing our proxies of the relative public and private indebtedness: $\left(D Q P D_{t}\right)$ and $\left(D Q P R D_{t}\right)$, respectively. These dummy variables take values from 1 to 4 , corresponding to the low indebted, lower middle indebted, upper middle

\footnotetext{
${ }^{11}$ Following Helliwell et al. (2014) the six composite measures reported by the World Bank are divided into two groups and only the average of the second group of indicators (which contains four measures primarily concerned with the quality of the delivery of government services: government effectiveness, regulatory quality, rule of law, and the control of corruption) is included in our analysis. The first group of two indicators measures the state of democracy and other aspects of the electoral process (voice and accountability, and political stability and absence of violence).

12 However, this does not include cross-border bank loans from the Bank for International Settlements dataset because they were not available for all the countries in our sample.

13 Outstanding debt securities are calculated on the basis of maturity at issuance.
} 
indebted, and high indebted categories using public and private debt-to-GDP ratios respectively.

With regard to the debt maturity variable, we use short-term debt $\left(S T D_{t}\right)$, expressed as percentage of total external debt, as a proxy. Data have been obtained from the World Bank's World Development Indicators and from the Coordinated Portfolio Investment Survey (CPIS) database provided by the IMF.

Finally, the International Monetary Fund Government Financial Statistics was the source used to collect data regarding government expenditure by purpose. This dataset is usually known as the classification of the functions of government (COFOG) and divides government expenditure into 10 categories: (GF01) on general public services, (GF02) on defence, (GF03) on public order and safety, (GF04) on economic affairs, (GF05) on environment protection, (GF06) on housing and community amenities, (GF07) on health, (GF08) on recreation, culture and religion, (GF09) on education, and (GF10) on social protection. A more detailed overview of the items included in each category is presented in Appendix $4^{14}$.

To produce a balance panel without missing values, we apply two complementary procedures: the technique of multiple imputation developed by King et al. (2001) (which permits the approximation of missing data and allows us to obtain better estimates) and the simultaneous nearest-neighbour predictors proposed by Fernandez-Rodriguez et al. 1999) (which infers omitted values from patterns detected in other simultaneous time series).

\section{Econometric Methodology}

Given the relatively small sample available, we use panel data econometrics to combine the power of cross section averaging with all the subtleties of temporal dependence (see Baltagi, 2008) ${ }^{15}$. Indeed, this methodology has already been extensively used in the literature.

\subsection{Time series properties}

Since the appropriate econometric treatment of a model depends crucially on the pattern of stationarity and non-stationarity of the variables under study, before carrying out the

\footnotetext{
${ }^{14}$ In each country, expenditure in the different groups is presented as a percentage of GDP.

${ }^{15}$ The main advantages over single cross-sections or time series data are the following: a) a more accurate inference of model parameters, b) a greater capacity for capturing the complexity of economic relationships, c) more informative results, d) a greater ability to control for individual unobserved heterogeneity, and e) its simpler computation and statistical inference. See Hsiao (2003) for an analysis of the advantages and limitations of using panel datasets.
} 
estimation we perform a variety of unit root tests in panel datasets. Specifically, we use the Levin-Lin-Chu (2002), Harris-Tzavalis (1999), Breitung (2000), Im-Pesaran-Shin (2003), and Fisher-type (Choi, 2001) tests. The results of these tests ${ }^{16}$ decisively reject the null hypothesis of a unit root for $g_{i t}, I N F_{i t}, P O P G R_{i t}$ and $G C F_{i t}$ (indicating that they are stationary in levels, i. e., $\mathrm{I}(0))$, while they do not reject the null for $y_{i t}, d_{i t}, O P E N_{i t}$ and $H K_{i t}$ (suggesting that these variables can be treated as first-difference stationary, i. e., I(1))

\subsection{Empirical model}

Given that our dependent variable is stationary (i.e., its statistical properties such as mean, variance, autocorrelation, etc., remain constant over time), we cannot explain it with nonstationary variables (whose statistical properties change over time). Additionally, if the variables in the regression model are not stationary, then the standard assumptions for asymptotic analysis will not be valid and we cannot undertake hypothesis tests about the regression parameters. Therefore, by differentiating the non-stationary variables we transform them into stationary variables.

As a result of the time series properties of our data, the baseline empirical model is as follows:

$$
g_{i t}=\alpha_{i}+\phi g_{i t-1}+\delta_{1} I N F_{i t}+\delta_{2} \Delta H K_{i t}+\delta_{3} \Delta O P E N_{i t}+\delta_{4} P O P G R_{i t}+\delta_{5} G C F_{i t}+\beta \Delta d_{i t}+\varepsilon_{i t}
$$

where $\Delta$ denotes the first difference operator.

Note that model (2) is quite different from model (1), which is commonly used in the literature, especially regarding the variables $y_{i-1}, H K_{i t}, O P E N_{i t}$ and $d_{i t}$, since we find that they are non-stationary and therefore enter our model in first differences. As argued in Asimakopoulos and Karavias (2016), by rewriting equation (1) as (3)

$$
g_{i t}=\alpha_{i}+\gamma y_{i t-1}+\sum_{j=1}^{l} \delta_{i j}^{s} X_{i j t}^{s}+\sum_{j=1}^{l} \delta_{i j}^{n s} X_{i j t}^{n s}+\beta d_{i t}+\varepsilon_{t}
$$

(where $X_{i j t}^{s}$ and $X_{i j t}^{n s}$ denote the stationary and non-stationary explanatory variables respectively), we can compare (3) with our equation (2), which has $g_{i t-1}=\Delta y_{i t-1}$ instead of $y_{i t-1}, \Delta d_{i t}$ instead of $d_{i t}$ and $\Delta X_{i j t}^{n s}$ instead of $X_{i j t}^{n s}$ as explanatory variables due to nonstationarity. The interpretation of the estimated parameters is the same in both models, but that of $\phi, \delta_{2}, \delta_{3}$ and $\beta$ changes.

\footnotetext{
16 The results of the tests are available upon request from the authors.
} 
To estimate model (2), we initially consider two basic panel regression methods. The first one is the pooled-OLS and is based on the following assumptions about unobserved terms:

- $\alpha_{i}$ is uncorrelated with $x_{i t}: E\left(x_{i t} \alpha_{i}\right)=0$

- $\quad x_{i t}=\left(g_{i t-1}, I N F_{i t}, \Delta H K_{i t}, \Delta O P E N_{i t}, P O P G R_{i t}, G C F_{i t}, \Delta d_{i t}\right)$

- $E\left(x_{i t} \varepsilon_{i t}\right)=0\left(x_{i t}\right.$ predetermined $)$

In this first estimation method, the data for different countries are pooled together and the equation is estimated by ordinary least squares (OLS).

The second method is the fixed-effects (FE) method, based on the following assumptions about unobserved terms $\left(\alpha_{i}\right.$ and $\left.\varepsilon_{i t}\right)$ :

- $\alpha_{i}$ is freely correlated with

- $\quad x_{i t}=\left(g_{i t-1}, I N F_{i t}, \Delta H K_{i t}, \Delta O P E N_{i t}, P O P G R_{i t}, G C F_{i t}, \Delta d_{i t}\right)$

- $E\left(x_{i t} \varepsilon_{i s}\right)=0$ for $s=1, \ldots, T$ (strict exogeneity)

Therefore, this second estimation method accounts for differences between countries and the constant terms $\alpha_{i}$ are allowed to vary between them. These constant terms stand for all unobserved aspects that distinguish the countries from each other (i. e., they capture country heterogeneity).

\subsection{Exploring the possibility of heterogeneous effects}

However, the originality of the analysis presented in this paper does not arise from the use of panel data techniques, but from exploring the possibility of heterogeneous effects of debt variations on economic growth, accounting for both varying and unvarying heterogeneity between countries using a recently developed method from the panel time series literature: the Grouped Fixed Effect (GFE) approach, proposed by Bonhomme and Manresa (2015) ${ }^{17}$. The GFE estimator relaxes the strict assumption that all countries follow the same time trend, and requires only that all countries within a group follow the same time pattern over time. Nevertheless, the GFE estimator restricts the pattern to being the same for all countries within a group, but allows different groups to have fully distinct time patterns.

\footnotetext{
17 This estimator has been used in Grunewald et al. (2017) to investigate the relationship between inequality and carbon dioxide emissions and by Oberlander et al. (2017) to assess the distinct effects of social globalization and trade openness on national trends in markers of diet quality.
} 
In contrast to the country fixed effects estimator, the GFE estimator can control for unobservable time-varying country characteristics that follow a group-specific time pattern. The main identifying assumption is that the number of distinct country-specific time patterns of unobserved heterogeneity is equal to the number of groups. In other words, all countries have to follow one of the group specific time-varying paths of unobserved heterogeneity.

An additional important feature of the GFE estimator is that group membership of the countries in our sample is not pre-determined, but is estimated according to a least-squares criterion. Countries whose time profiles of the outcome variable (growth rate of real per capita GDP) - net of the effect of covariates - are most similar are grouped together. Assume that the countries in our sample are categorized in a number of groups indexed by $j=1, \ldots, J$. The number of groups $J$ must be small compared to the number of countries.

Finally, a further advantage of the GFE estimator is that the time-varying GFE are better suited to deal with endogeneity in the presence of time-varying unobserved heterogeneity.

In this case, our regression equation takes the following specification:

$$
g_{i t}=\phi g_{i t-1}+\delta_{1} I N F_{i t}+\delta_{2} \Delta H K_{i t}+\delta_{3} \Delta O P E N_{i t}+\delta_{4} P O P G R_{i t}+\delta_{5} G C F_{i t}+\beta \Delta d_{i t}+\alpha_{j_{i}}+\varepsilon_{i t}
$$

where $\alpha_{j_{i}}$ denotes the group-specific time fixed effect which includes group fixed effects as well as time fixed effects. The estimator is described in detail in Appendix 5.

\section{Empirical Results ${ }^{18}$}

Table 1 shows the estimation results using the OLS, panel FE and GFE methodologies. It can be seen that the growth rate of real per capita GDP is negatively associated with changes in the public debt-to-GDP ratio. Compared to OLS and FE specifications, the coefficient of changes in the public debt-to-GDP ratio shrinks slightly in magnitude in the GFE estimation, but remains statistically significant. An additional point on the public debt-to-GDP ratio is associated with a reduction in the growth rate by 0.072 . A one standard deviation increase (8.93) in the public debt-to-GDP ratio reduces the rate of growth by about 0.64 on average, equivalent to a decrease of about $29 \%{ }^{19}$.

\footnotetext{
${ }^{18}$ In each model, we focus our comments on the variation in public debt in order to investigate its effect on growth, summarizing the results by pointing out the main regularities. The reader should browse through Tables 1 and 2 for a detailed account of the impact of other explanatory variables on the growth rate.

${ }^{19}$ The mean rate of growth during the sample period is 2.24 , being 0.64 the $29 \%$ of it.
} 
It is noticeable that the fit of the overall regressions significantly increases from 0.265 for the OLS and FE specifications to 0.544 for the GFE. Note also that the values of the objective function (the Bayesian information criterion, BIC) of the GFE estimation is lower than the values of the objective function of the OLS and fixed effects estimation, suggesting that some cross-country heterogeneity is time-varying in our sample and justifying the appropriate use of the GFE estimator.

\section{[Insert Table 1 here]}

The GFE model uses seven groups (the number being selected using information on the change in the criterion function). The estimated classification of the countries belonging to each group is shown in Table 2 and Figure 2.

[Insert Table 2 and Figure 2 here]

Next, in order to investigate whether variations in the public debt-to-GDP ratio have a different effect on the rate of growth in different groups, we estimated a new model that allows for specific slopes by including interactions of the variable $\Delta d_{i t}$ with the group indicator variables. Table 3 presents the impact of changes in debt-to-GDP ratio on real per capita GDP growth for the seven detected groups in the sample ${ }^{20}$.

[Insert Table 3 here]

It can be observed that the coefficient of the interaction term is negative and significant for all groups and that the estimated impact ranges between -0.43 in Group 1 to -0.031 in Group $7^{21}$.

Group 1 and Group 2, the ones with the highest effect of a debt change on economic growth (-0.43 and -0.23 respectively) are composed entirely by advanced and emerging market economies: four post-Soviet states in the case of Group 1 -three Baltic states, Estonia, Latvia and Lithuania, which are now advanced economies and members of the European Economic and Monetary Union (EMU) and one Eastern Europe country which is an emerging market economy (Ukraine)-; and five East Asia \& Pacific countries, one European and one sub-Saharan African country in the case of Group 2. Of these, two are advanced economies (Republic of Korea and Singapore) and five emerging market

\footnotetext{
${ }^{20}$ For expository convenience, we have named the endogenously identified groups according to their estimated impact, being Group 1 the one with the highest estimated impact and Group 7 the one with the lowest estimated impact.

21 These results imply that a one standard deviation increase on the public debt-to-GDP ratio reduces the rate of growth by about $60 \%$ in Group 1 while the same increase generates only a 10\% decrease in Group 7.
} 
economies (Indonesia, Malaysia, Thailand, Russia ${ }^{22}$ and Botswana). A common characteristic of countries that belong to Groups 1 and 2 is that they present low or moderate levels of public debt-to-GDP throughout the sample. The only exception is Singapore, with an average ratio above $90 \%$ throughout the period.

The estimated impact of a debt change on economic growth declines noticeably in Group 3 (-0.14), which includes 16 countries: two post-Soviet states from Eastern Europe, Moldova $^{23}$ a low-income developing country and Belarus, an emerging market economy; four European countries, three of them considered emerging markets (Turkey, Bulgaria and Romania, the last two are members of the European Union) and one advanced economy that is a member of the EMU (Slovak Republic); nine Latin American countries (Brazil, Argentina, Chile, Colombia, Ecuador, Honduras, Panama, Paraguay and Peru) which are considered emerging economies by the IMF with the exception of Honduras (a low-income developing country); and one sub-Saharan African country (Namibia) which is also an emerging market economy. With the exception of Brazil, all of them also present moderate levels of public debt during the sample period ${ }^{24}$.

Group 4 and Group 5 present lower impacts (-0.11 and -0.09 respectively) and mainly include advanced and emerging market economies (though there are also some low-income developing countries), but the average ratios of both public and private debt are much higher $^{25}$. Specifically, Group 4 comprises three advanced economies that belong to the EMU (Ireland ${ }^{26}$, Luxembourg and Malta); one Latin American country (Dominican Republic), an emerging market economy, and two sub-Saharan African countries (Seychelles, an emerging market country and Cape Verde a low-income developing country). Group 5, with 40 countries, is the largest, followed by Group 7 with 31 countries - 21 European countries (12 advanced economies that belong to the EMU: Austria, Belgium, Cyprus, Finland, France, Germany, Greece, Italy, the Netherlands, Portugal,

\footnotetext{
22 Russia is one of the EM economies that now issues almost all its debt in local currency. While this shift has reduced currency risk, it has also fostered an increase in the share of debt held by non-residents (who are traditionally more volatile)

${ }^{23}$ Fraud in Moldova's banking system led to a large government bailout in 2014.

${ }^{24}$ However, Brazil made a shift to issue its debt in local currency, which has reduced currency risk. Conversely, in Argentina, despite having a lower level of public debt, indebtedness may represent a risk since it is mainly external and can lead to a balance of payments or a currency crisis. Indeed, Argentina has recently experienced significant capital outflows (a similar crisis took place in Turkey, which is also in Group 3).

${ }^{25}$ The average debt ratio of $100 \%$ is surpassed by one country in Group 4 (Seychelles) and by six in Group 5 (Japan, Mauritania, Greece, Jamaica, Italy and Belgium); whilst this ratio of $80 \%$ is surpassed by one country in Group 4 (Cape Verde) and by five in group 5 (Barbados, Belize, Canada, Comoros, and Portugal).

${ }^{26}$ In Ireland (jointly with Luxembourg and Malta), the effect of a debt change on economic growth is higher than in most of the euro area countries (the majority belong to Group 5). The fact that exposure to foreign creditors is traditionally very high in Ireland (more than 40\%) and that a major banking crisis led to a government bailout in 2010 (the debt-toGDP ratio surpassed $100 \%$ between 2011 and 2014 ) might partially explain this difference.
} 
Slovenia and Spain; six EU countries outside the currency union: the Czech Republic, Denmark, Sweden, the United Kingdom, advanced economies, and Croatia and Hungary, emerging market economies; and three other European advanced economies that do not belong to the EU: Iceland, Norway and Switzerland; two advanced North American economies (Canada and the United States); three East Asia and Pacific countries (Japan and New Zealand, advanced economies, and Fiji, an emerging market economy); eight Latin American and Caribbean countries (the Bahamas, Barbados, Belize, El Salvador, Jamaica and Mexico, emerging markets, and Nicaragua and Haiti, low-income developing countries); three Middle East and North African countries (Israel, Algeria and Iran), the first being an advanced economy and the other two emerging markets belonging to the Organization of the Petroleum Exporting Countries (OPEC); and three sub-Saharan African countries (South Africa ${ }^{27}$, an emerging market, and Comoros and Mauritania lowincome developing countries).

Finally, in Groups 6 and 7 the estimated effect of a debt change on economic growth registers the lowest values (-0.04 and -0.03 respectively). They are composed entirely of emerging markets and low-income developing countries with somewhat more moderate debt levels, especially in Group 7. More specifically, Group 6 comprises 12 countries, and some of them with high public debt ratios ${ }^{28}$ : eight sub-Saharan African countries (Congo Republic, Congo Democratic Republic, Côte d'Ivoire, the Gambia, Madagascar, Mali, Niger and Gabon) that with the exception of Gabon (an emerging market and member of OPEC) are low-income developing countries; three Middle East and North African countries (Morocco, Oman and Saudi Arabia - emerging markets and, in the case of the last two, oil exporters (Saudi Arabia also belongs to OPEC) and one South Asia lowincome developing country (Nepal). Group 7, the second-largest with 31 countries, includes $^{29}: 14$ sub-Saharan African countries (Burkina Faso, Cameroon, Ghana, Guinea, Kenya, Malawi, Nigeria, Rwanda, Sudan, Tanzania, Uganda, Eswatini, Mauritius, and

${ }^{27}$ South Africa, and to a lesser extent Mexico are also among the EMs countries that made a shift in their debt structure to local currency.

${ }^{28}$ This is the case of Republic of Congo, Côte d'Ivoire, Madagascar and the Gambia. It is noticeable that, in the Republic of Congo (an OPEC member) the collapse of the oil price in 2012-2013 was a major factor in the debt increase that led the country into default with external creditors and face difficult restructuring discussions; however, fraud and corruption were a major factor of fiscal deterioration in other countries such as the Gambia.

${ }^{29}$ Although average public debt-to-GDP ratios are more moderate than in Groups 4, 5 and 6, they are also high in some countries (e.g. Cameroon, Egypt, Ghana, Guyana, Jordan, Kyrgyz Republic, Kenya, Malawi, Rwanda, Sri Lanka and Sudan). It is noticeable that in oil exporter countries (e.g., Egypt and Sudan) the fall of the oil price in 2012-2013 was a major driver of debt increase; however, fiscal positions also deteriorated after 2012 in some diversified exporter economies. The factors of declining fiscal positions are quite diverse, and include current spending overruns (e.g. Ghana and Kyrgyz Republic) or spending on major projects (e.g. Cameroon, Kenya and Rwanda). However, China and India (also in Group 7) are among the largest EMs that now issue virtually all their debt in local currency and have become (jointly with Brazil) the dominant source of bilateral financing to LIDC, who have seen a dramatic shift in their creditor base. 
Senegal) which are low-income developing countries (oil exporters in the case of Sudan and Nigeria, which is also an OPEC member) with the exception of the last three, which are emerging markets; four Middle East and North African countries (Bahrain, Egypt, Jordan and Tunisia) which are emerging markets (Egypt being an oil exporter); five Latin American and Caribbean countries (Bolivia, Costa Rica, Guatemala, Uruguay and Guyana) which are emerging markets with the exception of Guyana (a low-income developing country); three South Asian countries (India, Pakistan and Sri Lanka); two East Asia and Pacific countries (China and Philippines) which are also emerging markets; and, finally, three European countries: two post-Soviet states (Kazakhstan, an emerging market and oil exporter, and Kyrgyz Republic, a low-income developing country) and an European Union country that is classified as an emerging market economy (Poland).

So, all in all, we observe that the effect of a change in the public debt-to-GDP ratio on GDP growth is lower in developing and emerging market economies (where, in general, the level of public indebtedness is also lower) than in advanced economies that record the highest ratios of public debt (see Figure 1$)^{30}$. However, since the richest countries in the world do not belong to Group 1 (the ones with the highest effect of a debt change on economic growth), but to Group 5, there must be other reasons that might explain group membership. For this reason, in the next section we examine the relevance of the institutions, the type of expenditure that is funded with debt, the relative level of private and public indebtedness, and debt maturity in explaining the debt-growth relationship.

Moreover, we investigate whether the heterogeneous impact detected has a different pattern over time by estimating a new model that allows for specific time-varying slopes including interactions of the variable $\Delta d_{i t}$ with the group indicator and year dummies ${ }^{31}$. Figure 3 shows the estimated evolution of the coefficient of changes in the public debt-toGDP ratio on economic growth by country groups over time. As can be seen, there is time-varying heterogeneity within and between country groups.

[Insert Figure 3 here]

It can be observed that the more volatile the estimated effect over time (measured by the standard deviation), the higher the impact. It is quite stable in Groups 6 and 7 and records the highest volatility in Group 1. It is also noticeable that, in four out of the seven groups

30 The gap between the debt of the G20 advanced and emerging market economies is still significant, exceeding $90 \%$ of GDP on average, while low-income developing countries are even clearer outliers, accounting for less than $1 \%$ of the global debt - well below their share of output (see Mbaye et al., 2018).

31 The estimation results are not shown here to save space, but they are available from the authors upon request. 
(1, 2, 3 and 5), the negative estimated effect of a debt change on economic growth reaches its maximum value (in absolute terms) during the period 2010-2012, coinciding with the Great Recession (2007-2013) ${ }^{32}$-the exceptions are Group 4, where the highest estimated effect takes place in 2006 (before the financial crisis), and Groups 6 and 7 where the coefficient is quite stable over time-. However, while in Groups 3 and 5 this high negative effect vanishes very quickly, in Groups 1 and 2 its duration is longer.

\section{Explaining group membership and time-varying impact}

In this section we assess the role of five types of variables as underlying drivers of the heterogeneous impact of debt on economic growth: (1) the quality of institutions $\left(G Q I_{t}\right)$, (2) the composition of public expenditure that is funded with debt (the 10 groups into which the classification of the functions of government (COFOG) divides government's expenditure, see Appendix 4), (3) the relative ratio of private debt indebtedness ( $D Q P R D t)$, (4) the relative ratio of public debt indebtedness $\left(D Q P D_{t}\right)$, and (5) debt maturity $\left(S T D_{t}\right)$.

With regard to the first variable, the role of sound and efficient institutions in explaining long-run growth was formalized in a number of contributions in the early 2000s, which showed that countries with weaker institutions find it harder to sustain growth and are more vulnerable to experiencing periods of crisis and stagnation ${ }^{33}$ (see Acemoglu et al. 2001, 2002, 2005a and 2005b). However, the role played by institutions in explaining the relationship between debt and growth has for the most part been ignored. To the best of our knowledge, the exceptions are Jalles (2011), Kourtellos et al. (2013), and Kim et al. (2017)) who find empirical evidence suggesting that the quality of governance, the control of corruption and the level of democracy are relevant factors influencing the relationship between debt and economic growth.

Regarding the relationship of expenditure composition and economic growth, there is also a large body of literature on this issue but, as far as we know, no empirical paper has examined the effect of the above variables in the debt-growth nexus, in spite of its relevance. In this connection, Devarajan et al. (1996) and Aschauer (1989) point out that the impact of public debt on the economy's performance may depend on whether the public expenditure funded by government debt is productive or unproductive. While the

\footnotetext{
32 According to Eichengreen et al. (2019), about two-thirds of the increase in the advanced-country debt ratio during the Great Recession was accounted for by the cumulative increase in the primary deficit, reflecting revenue losses and expansionary fiscal policies.

33 Good institutions might induce higher investment and therefore lead to sustainable economic growth, and might also reduce uncertainty for economic decision-makers and offer incentives for innovative and productive activities.
} 
former, which includes physical infrastructure (roads and railways), communication, information systems (phone, internet), education, health-care, and social protection ${ }^{34}$ may have a positive impact on the growth rate of the economy, the latter does not affect the economy's long-run performance, although it may have positive short-run implications. Therefore, the purpose to which debt is put is highly relevant, since while there are good reasons to issue debt, there have also been political failures that have induced governments to borrow more than is socially desirable (funding unproductive public expenditure) which may lead, in some cases, to public debt levels that are hard to justify.

With regard to private debt, we should recall that according to the Global Debt Database published by the IMF, of the global total debt at the end of 2017 (\$184 trillion in nominal terms, the equivalent of $225 \%$ of GDP), only one-third was public debt, the remaining two-thirds being nonfinancial private debt (debt held by households and nonfinancial corporations). While the unprecedented increase in public debt and its scale have raised serious concerns among economists both about its sustainability and about its impact on economic growth, they have taken a more nuanced position on the risks of private debt accumulation [Cecchetti et al. (2011), Lombardi et al. (2017) and Gómez-Puig and SosvillaRivero (2018a) are some of the exceptions]. Nevertheless, all forms of debt, when they are high and moving upwards, are sources of justifiable concern. In particular, the negative implications of excessive private debt (a "debt overhang") for growth and financial stability are well documented in the literature, underscoring the need for private sector deleveraging in some countries. In this regard, some authors [see, e.g., Schularick and Taylor (2012) and Jordà et al. (2016)] demonstrate that high debt levels in the private sector are not only a good predictor of financial crises, but also a key determinant of the intensity of the ensuing recession. Moreover, high private debt levels can also hamper growth even in the absence of a financial crisis, since the accumulation of debt involves risk (International Monetary Fund, 2016). As debt levels increase, borrowers' ability to repay becomes progressively more sensitive to falls in income and sales as well as to increases in interest rates. In fact, high private debt can have a substantial adverse impact on macroeconomic performance and stability, as it hinders the ability of households to smooth their consumption, and affects corporations' investments. So, as indicated in Section 4, we use yearly data to create

\footnotetext{
34 Although some sort of this investment might not be profitable from the single firm's point of view (as private costs exceed private returns), the whole economy would nevertheless benefit enormously, which justifies public provision. For instance, Glomm and Ravikumar (1997), among others, contend that both government infrastructure investment and education expenditures have a significant impact on an economy's long-term growth rate. Afonso and Halles (2014) and Beraldo et al. (2009) show that spending on education and health boosts growth. Finally, Herce et al. (2000, 2001) find a positive growth effect of total social protection expenditure in the European Union.
} 
two dummy variables representing our proxies of the relative public and private indebtedness: $\left(D Q P D_{t}\right)$ and $\left(D Q P R D_{t}\right)$, respectively. These dummy variables take values 1 to 4 corresponding to the low indebted, lower middle indebted, upper middle indebted, and high indebted categories using public and private debt-to-GDP ratios respectively.

Finally, Fatás et al. (2019) stated that one of the reasons why it is difficult to identify common patterns and to pin down the causal effect of debt on growth is that not all debts are equal; factors such as debt maturity are key elements that can affect fiscal vulnerabilities and the responses of governments to debt changes. Therefore, as a proxy of debt maturity, we have introduced short-term debt expressed as percentage of total external debt $\left(S T D_{t}\right)$.

In order to assess the effects of the different factors jointly, we run multinomial logit regressions of the seven estimated groups, using several specifications (see Pindyck and Rubinfeld, 1998) ${ }^{35}$. Table 4 presents classification success data for four multinomial logistic regression models sequentially employing different categories of the selected independent variables. A look at Table 4 reveals that, except for the indicator of quality of institutions, the estimated models achieve a high classification success, and are able to render predicted probabilities that are close to the actual percentage frequency observed in the data. Therefore, the results suggest that the explanatory variables contain useful information that allows accurate replication of the country classification generated by the GFE estimation procedure.

\section{[Insert Table 4 here]}

To further analyse the potential determinants of the identified heterogeneous group effects of public debt variations on growth, we run regressions of the time-varying coefficients of changes in the public debt-to-GDP ratio on economic growth by country groups (depicted in Figure 3) on their potential drivers. To overcome the problem of coefficient comparison when the variables are measured in different units, we use standardized coefficients to evaluate the relative importance of the different explanatory variables. To this end, following the proposal of Bring (1994), we use the variance inflation factor to calculate partial standard deviations that provide standardized coefficients directly related to the

\footnotetext{
35 The results of the multinomial logistic regression estimations are not shown here to save space, but they are available from the authors upon request.
} 
reduction in $\mathrm{R}^{2}$ obtained by excluding the variable from the model ${ }^{36}$. Table 5 displays the results.

\section{[Insert Table 5 here]}

It can be seen that the variable that captures the quality of the institutions $\left(\mathrm{GQI} I_{t}\right)$ has a positive significant impact in the relationship between a debt change and growth in five out of the seven groups (the exceptions being Groups 1 and 4), meaning that, the sounder the institutions, the less negative or the more positive the effect of a public debt increase on economic growth. This implies that $G Q I_{t}$ has a positive moderating effect on the relationship between public debt and economic growth, in agreement with Jalles (2011), Kourtellos et al. (2013), and Kim et al. (2017), who also found empirical evidence that the quality of governance, the control of corruption and the level of democracy are relevant factors influencing the relationship between debt and economic growth. The variable that gauges the relative level of public indebtedness $\left(D Q P D_{t}\right)$ registers a negative impact in the debt-growth nexus in four groups of countries (1, 2, 5 and 6). Interestingly, on average, the relative level of public debt is low in Groups 1 and 2, while it is high in Groups 5 and 6. These results suggest that the threshold beyond which an increase in public debt has a negative effect on economic growth differs across countries (see, e.g., Edberhardt and Presbitero (2015) or Chudik et al. (2017)). Specifically, this threshold is much lower in countries in Groups 1 and 2 (i.e., the room for manoeuvre for increasing public debt is very limited, even when their level of public indebtedness is already low) than in Group 5 and 6 countries (where the estimated effect of a debt increase on growth is much lower, although their level of public indebtedness is considerably higher). As for the relative level of private indebtedness $\left(D Q P R D_{t}\right)$ it turns out to have a significant negative impact on the debtgrowth relationship in two groups of countries ( 2 and 5 , which are mainly integrated by advanced economies, especially Group 5) where the level of private indebtedness is very high (see Table 3), in line with the results presented by Schularick and Taylor (2012) or Jordà et al. (2016), among others, who pointed out the negative implications of excessive private debt for growth and financial stability. Turning to the case of the relationship of expenditure composition and the debt-growth relationship, our results reinforce the idea that the impact of a public debt increase on the economy's performance might depend on whether the public expenditure funded by government debt is productive or unproductive [see Aschauer (1989), Devarajan et al. (1996)]. It can be observed that, if public debt funds

\footnotetext{
${ }^{36}$ See Appendix 6 for further details.
} 
unproductive expenditure [GF01 (general public services), GF02 ${ }_{t}$ (defence), and GF08 (recreation, culture and religion)], its impact on economic growth is negative (in four and five out of seven groups in the case of $\mathrm{GFO1}_{t}$ and $\mathrm{GF08}$ t respectively). However, if sovereign debt funds expenditure in some of the other seven groups into which government expenditure is divided according to the classification of the functions of government (COFOG), the impact on economic growth is positive in some groups of countries. Specifically, the groups of expenditure where a rise in spending implies a positive impact on the debt-growth nexus in more groups of countries are: GF04 (economic affairs, which includes roads, railways, communication, and information systems, and has a positive effect in five out of the seven groups), GF09 (education, which also has a positive effect in five out of the seven groups of countries), and GF10 (social protection, which registers a positive impact in six out of the seven groups, the only exception being Group 5 , the countries with the highest level of social protection). A rise in expenditure in the other four groups of public spending only affects the debt-growth nexus positively in two or three out of the seven groups. In particular, a rise in $\mathrm{GFO5}_{t}$ (environmental protection, including sewage system operation) implies a positive impact in the debt-growth relationship in countries in Groups 1, 6, and 7 (we should recall that Groups 6 and 7 include some of the lowest-income developing countries in our sample), while a rise in GF03 (public order and security, including law courts), in GF06 (housing and community amenities) and in $\mathrm{GFO7}_{t}$ (health) is associated with a positive impact in the debt-growth nexus in countries in Groups 3 and 5, Groups 2 and 6, and Groups 1 and 4, respectively. Finally, the higher the proportion of short-term debt, the more negative the impact of an increase in debt on economic growth in the seven group of countries (the impact being especially high in Group 4) as pointed out by Fatás et al. (2019). 


\section{Concluding remarks}

In this paper we have used the GFE method proposed by Bonhomme and Manresa (2015) as opposed to a standard fixed effects estimator to examine whether the debt-growth relationship might differ substantially across different groups of countries, using a sample that comprises 116 advanced, emerging and developing economies over the period 19952016. To the best of our knowledge, this is the first paper to apply the GFE methodology to examine the heterogeneous relationship between public debt and economic growth both across countries and over time. The GFE accounts for unobserved time-varying heterogeneity across groups of countries in panel data models, group membership being estimated along with the other parameters in the model by minimizing the sum of squares of residuals. Moreover, this paper also contributes to the literature by analysing the drivers of the heterogeneous impact of debt on economic growth. To that end, we first explore the determinants of group membership, making use of a multinomial logit regression model to assess the role of five types of variables: (1) the quality of institutions, (2) the composition of public expenditure funded with debt, (3) the relative public indebtedness, (4) the relative private indebtedness, and (5) the maturity of debt. We then analyse the role of these variables in explaining the time-varying impact of public debt on growth in the country groups identified. Our paper therefore shifts the focus of research on the long-run effects of "high levels" of public debt towards its interplay with the deep determinants of growth (institutions and public policies) as the new growth theories have recently proposed (see, e. g., Capolupo, 2009).

Our findings suggest that the relationship between public debt and growth varies across countries. In particular, the GFE estimator endogenously splits the sample into seven groups of countries that have dissimilar time patterns and a different estimated impact of a debt change on economic growth (ranging from -0.43 in Group 1 to -0.031 in Group 7). When analysing the heterogeneous time-varying impact of public debt on growth, our results indicate that the debt-growth relationship is crucially mitigated by the quality of a country's institutions and intensified by the level of both public and private indebtedness and the maturity of debt. The type of expenditure that is funded with debt also influences that relationship (negatively in the case of unproductive spending, and positively in the case of productive spending).

Regarding policy implications, our results indicate that the nexus between public debt and economic growth differs according to country and is crucially related to diversity in 
institutions and public policies that make up the socio-economic environment. Therefore, we consider that our results may have some practical meaning for national policymakers and international organizations responsible for global economic surveillance, and provide theoretical insights for academic scholars interested in the identification of growth determinants and factors responsible for the differences in growth in the data observed.

\section{Acknowledgements}

The authors are very grateful to Angel Valarezo-Unda for his assistance with the research and to Julián Andrada-Félix and Eduardo Acosta-González for their useful suggestions.

\section{Funding}

This paper is based on work supported by the Spanish Ministry of Economy and Competitiveness [grants ECO2016-76203-C2-2-P and ECO2017-83255-C3-3-P (AEI, FEDER, EU)] and from Universitat Jaume I [project UJI-B2017-33]. 


\section{References}

Acemoglu, D., S. Johnson and J. Robinson. 2001. The Colonial Origins of Comparative Development: An Empirical Investigation. American Economic Review 91, 1369-1401.

Acemoglu, D., S. Johnson and J. Robinson. 2002. Reversal of Fortune: Geography and Institutions in the Making of the Modern World Income Distribution. Quarterly Journal of Economics, November, 1231-1294.

Acemoglu, D., S. Johnson and J. Robinson. 2005a.The rise of Europe: Atlantic Trade, Institutional Change and Economic Growth. American Economic Review 95(2), May, 546-579.

Acemoglu, D., S. Johnson and J. Robinson. 2005b. Institutions as a Fundamental Cause of Long-Run Growth. Handbook of Economic Growth 1A: 386-472. Edited by Philippe Aghion and Steven N. Durlauf. Elsevier Ed.

Afifi, A. A., Clarke, V. 1990. Computer Aided Multivariate Analysis (2nd ed.). New York: Van Nostrand Reinhold.

Afonso, A., Jalles, J. T. 2014. Fiscal composition and long-term growth. Applied Economics 46: 349_ 358.

Aghion, P, Howitt, P. 2009. The Economics of Growth. The MIT Press Cambridge, Mass.

Alesina, A., Favero, C., and Giavazzi, F. 2019a. Effects of Austerity: Expenditure- and Tax-based Approaches. Journal of Economic Perspectives 33 (2): 141-162.

Alesina, A., Favero, C., and Giavazzi, F. 2019b. Austerity: When it Works and When it Doesn't. Princeton University Press.

Asimakopoulos, S., Karavias, Y. 2016. The impact of government size on economic growth: A threshold analysis. Economics Letters 139, 65-68

Aschauer, D. A. 1989. Is public expenditure productive? Journal of Monetary Economics 23, 177-200.

Baltagi, B. D. 2008. Econometric analysis of panel data, fourth ed. Chichester: John Wiley \& Sons.

Barro, R. J. 2003. Determinants of economic growth in a panel of countries. Annals of Economics and Finance 4, 231-274.

Beltratti, A., Stulz, R.M., 2012. The credit crisis around the globe: why did some banks perform better? Journal of Financial Economics 105, 1-17.

Beraldo, S., Montolio, D., Turati, G. 2009. Healthy, educated and wealthy: A primer on the impact of public and private welfare expenditures on economic growth. Journal of Socio-Economics 38(6): 946-956.

Bonhomme, S., and Manresa, E. 2015. Grouped patterns of heterogeneity in panel data. Econometrica 83, 1147-1184

Bredenkamp, H., Hausmann, R., Pienkowski, Al, Reinhart, C. 2019. Challenges Ahead. In Sovereign Debt: A Guide for Economists and Practitioners. Ali Abbas, Alex Pienkowski and Kenneth Rogoff, editors. Chapter 9. London: Oxford University Press, 2019.

Breitung, J. 2000. The local power of some unit root tests for panel data. In Advances in Econometrics, Volume 15: Nonstationary Panels, Panel Cointegration, and Dynamic Panels, edited by B. H. Baltagi, T. B. Fomby and R. C. Hill. B. H. Baltagi, 161-177. Emerald Group Publishing Limited.

Bring, J. 1994. How to Standardize Regression Coefficients. The American Statistician 48, 209-213.

Cecchetti, S. G., Mohanty, M., Zampolli, F. 2011. The real effects of debt. In: Economic Symposium Conference Proceedings. Federal Reserve Bank of Kansas City, 145-196.

Chiu, Y.B.; Lee, C.C. 2017. On the impact of public debt on economic growth: does country risk matter? Contemporary Economic Policy 35 (4), 751-766.

Choi, I. 2000. Unit root tests for panel data. Journal of International Money and Finance 20, 249-272.

Chong, A., Gradstein, M., 2007. Inequality and institutions. Review of Economics and Statistics 89, 454 465.

Chudik, A., Mohaddes, Pesaran, K., Raissi, M. 2017. Is there a debt-threshold effect on output growth? Review of Economics and Statistics 99, 135-150. 
Capolupo, R. 2009. The new growth theories and their empirics after twenty years. Economics: The Open-Access, Open-Assessment E-Journal, 3, 2009-1

Devarajan, S., Swaroop, V. \& Zou, H. (1996). The composition of public expenditure and economic growth. Journal of Monetary Economics, 37, 313- 344.

Eberhardt, M., Presbitero, A.F. 2015. Public debt and growth: Heterogeneity and non-linearity. Journal of International Economics 97, 45-58.

Eichengreen, B.; El-Ganainy, A.; Esteves, R.P; Mitchener, K.J. 2019. Public debt through the Ages. IMF Working Paper 19/6.

Fantom, N., Serajuddi, U. 2016. The World Bank's Classification of Countries by Income. Policy Research Working Paper 7528. The World Bank, Washington, DC

Fatás, A., Ghosh, A.R., Panniza, U., Presbitero, A.F. 2019. The Motives to Borrow. IMF Working Paper 19/101.

Fernandez-Rodriguez, F., Sosvilla Rivero, S., Andrada-Felix, J. 1999. Exchange-rate forecasts with simultaneous nearest-neighbour methods: Evidence from the EMS. International Journal of Forecasting 15, 383-392.

Fischer, S. 1993. The role of macroeconomic factors in growth. Journal of Monetary Economics 32, 485-512.

Frankel, M. 1962. The production function in allocation and growth: A synthesis. American Economic Review 52, 996-1022.

Gómez-Puig, M., Sosvilla-Rivero, S. 2017. Heterogeneity in the debt-growth nexus: Evidence from EMU countries. International Review of Economics and Finance, Vol. 51, 470-486.

Gómez-Puig, M., Sosvilla-Rivero, S. 2018a. Nonfinancial debt and economic growth in euro-area countries. Journal of International Financial Markets, Institutions and Money 56, 17-37.

Gómez-Puig, M. and Sosvilla-Rivero, S. 2018b. Public debt and economic growth: Further evidence for the euro area. Acta Oeconomica 68 (2), 209-229.

Ghosh, A. R., Kim, J.I., Mendoza, E. G., Ostry, J.D., Qureshi, M.S. 2013. Fiscal fatigue, fiscal space and debt sustainability in advanced economies. The Economic Journal 123, F4-F30.

Grossman, G., Helpman, E. 1991. Innovation and growth in the global economy. Cambridge, Massachusetts: MIT Press.

Grunewald, N., Klasen, S., Martinez-Zarzoso, I., Muris, C. 2017. The trade-off between income inequality and carbon dioxide emissions. Ecological Economics 142, 249-256.

Guajardo, J., Leigh, D. and Pescatori, A. 2014. Expansionary austerity: new international evidence, Journal of the European Economic Association, vol. 12(4), 949-68.

Hansen, B.E., 2017. Regression kink with an unknown threshold. Journal of Business, Economics and Statistics 35 (2), 228-240.

Harris, R. D. F., Tzavalis, E. 1999. Inference for unit roots in dynamic panels where the time dimension is fixed. Journal of Econometrics 91: 201-226.

Helliwell, J.F., Huang, H. Grover, S., Wang, S. 2014. Good Governance and National Well-being: what are the linkages? OECD Working Papers on Public Governance, No. 25, OECD Publishing.

Herce, J. A., Sosvilla-Rivero, S., de Lucio, J. J. 2000. Social protection benefits and growth: Evidence from the European Union. Applied Economics Letters 7: 255-258.

Herce, J. A., Sosvilla-Rivero, S., de Lucio, J. J. 2001. Growth and the welfare state in the EU: A causality analysis. Public Choice 109: 55-68.

Hsiao, C. 2007. Panel data analysis: Advantages and challenges. Test, 16, 1-22.

International Monetary Fund. 2016. Debt-Use it wisely. Fiscal Monitor, October, Washington DC. International Monetary Fund, 2018. World Economic Outlook, October, Washington DC.

Im, K. S., M. H. Pesaran, and Shin, Y. (2003). Testing for unit roots in heterogeneous panels. Journal of Econometrics, 115, 53-74.

Jalles, T.J. 2011. The impact of democracy and corruption on the debt-growth relationship in developing countries. Journal of Economic Development 36, 41-72.

Jordà, O., \& Taylor, A. M. (2016). The time for austerity: Estimating the average treatment effect of fiscal policy. The Economic Journal 126, 219-255. 
Jordà, O. Schularick, M., Taylor, A.M. 2016. Sovereigns versus banks: credit, crises and consequences. Journal of the European Economic Association 14, 45-79.

Kaufmann, D., Kraay, A., Mastruzzi, M. 2010. The Worldwide Governance Indicators: Methodology and Analytical Issues. The World Bank Policy Research Working Paper 5430. Washington DC.

Kim, E.; Ha, Y.; Kim, S. 2017. Public Debt, Corruption and Sustainable Economic Growth. Sustainability 9 (3), 433.

King, G., Honaker, J. Joseph, A,. Scheve, K., 2001. Analyzing incomplete political science data: An alternative algorithm for multiple imputation. American Political Science Review 95, 49-69.

Kourtellos, A., Stengos, T., Tan, C.M. 2013. The effect of public debt on growth in multiple regimes. Journal of Macroeconomics 38, 35-43.

Levin, A., C.-F. Lin, and Chu, C.-S. J. 2002. Unit root tests in panel data: Asymptotic and finitesample properties. Journal of Econometrics 108, 1-24.

Lof, M., Malinen, T. 2014. Does sovereign debt weaken economic growth? A panel VAR analysis. Economics Letters 122, 403-407.

Lombardi, M., Mohanty, M., Shim, I. 2017. The real effects of household debt in the short and long run. Working Papers No 607, Bank for International Settlements, Basel.

Markus, A., Rainer, S. 2016. Public debt and economic growth: Economic systems matter, Discussion Paper 281, Center for European Governance and Economic Development Research, Göttingen.

Mbaye, S., Moreno-Badia, M., and Chae, K. (2018). Global debt database: Methodology and sources. Working Paper 18/111, International Monetary Fund, Washington, DC.

Mitze, T., Matz, F. 2015. Public debt and growth in German federal states: What can Europe learn? Journal of Policy Modeling 37, 208-228.

Oberlander, L., Disdier, A-C., Etilé, F. 2017. Globalization and national trends in nutrition and health: A grouped fixed-effects approach to intercountry heterogeneity. Health Economics 26 (9), 1146-1161.

Pattillo, C., Poirson, H., Ricci, L.A. 2011. External debt and growth. Review of Economics and Institutions 2, 1-30.

Pescatori, A., Sandri, D., Simon, J. 2014. Debt and growth: Is there a magic threshold? Working Paper 14/34, International Monetary Fund, Washington D. C.

Pindyck, R., Rubinfeld, D., 1998. Econometric Models and Financial Forecasts, fourth edition. McGrawHill, Boston, Mass.

Reinhart, R., Rogoff, K. 2010. Growth in a time of debt. American Economic Review 100, 573-578.

Romer, P.M. 1992. Two strategies for economic development: Using ideas and producing ideas. World Bank Economic Review 6 (Sup 1), 63-91.

Sachs, J.D., Warner, A.W. 1997. Fundamental sources of long-run growth. American Economic Review 87, 184-188.

Schularick, M., Taylor, A.M. 2012. Credit booms gone bust: Monetary policy, leverage cycles, and financial crises, 1870-2008. American Economic Review 102, 1029-1061.

Seghezza, E., Baldwin, R.E. 2008. Testing for trade-induced investment-led growth. Economia Internazionale/International Economics 61, 507-537.

Solow, R. M. 1956. A Contribution to the theory of economic growth. Quarterly Journal of Economics 70, 65-94.

Woo, J., Kumar, M. S. 2015. Public debt and growth. Economica 82, 705-739.

World Bank. 1990. World development report 1990: Poverty. Oxford University Press, New York.

Yang, L., Su, J.J. 2018. Debt and growth: Is there a constant tipping point? Journal of International Money and Finance 87, 133-143.

Yared, P. 2019. Rising Government Debt: Causes and Solutions for a Decades-Old Trend. Journal of Economic Perspectives 33 (2): 115-140. 


\section{Appendix 1. The 116 countries included in the sample}

\begin{tabular}{|c|c|}
\hline Income group & Countries \\
\hline $\begin{array}{l}\text { 29 Low income } \\
\text { developing countries } \\
\text { (LIDC) }\end{array}$ & $\begin{array}{l}\text { Burkina Faso, Cameroon, Cape Verde, Comoros, Congo Republic, Congo Democratic } \\
\text { Republic, Côte d'Ivoire, The Gambia, Ghana, Guinea, Guyana, Haiti, Honduras, Kenya, } \\
\text { Kyrgyz Republic, Madagascar, Malawi, Mali, Mauritania, Moldova, Nepal, Nicaragua, } \\
\text { Niger, Nigeria, Rwanda, Senegal, Sudan, Tanzania, Uganda. }\end{array}$ \\
\hline $\begin{array}{l}54 \text { Emerging market } \\
\text { economies (EM) }\end{array}$ & $\begin{array}{l}\text { Algeria, Argentina, The Bahamas, Bahrain, Barbados, Belarus, Belize, Bolivia, Botswana, } \\
\text { Brazil, Bulgaria, Chile, China, Colombia, Costa Rica, Croatia, Dominican Republic, } \\
\text { Ecuador, Egypt, El Salvador, Eswatini, Fiji, Gabon, Guatemala, Hungary, India, } \\
\text { Indonesia, Iran, Jamaica, Jordan, Kazakhstan, Malaysia, Mauritius, Mexico, Morocco, } \\
\text { Namibia, Oman, Pakistan, Panama, Paraguay, Peru, Philippines, Poland, Romania, } \\
\text { Russia, Saudi Arabia, Seychelles, South Africa, Sri Lanka, Thailand, Tunisia, Turkey, } \\
\text { Ukraine, Uruguay. }\end{array}$ \\
\hline $\begin{array}{c}33 \text { Advanced economies } \\
\text { (AE) }\end{array}$ & $\begin{array}{l}\text { Austria, Belgium, Canada, Cyprus, Czech Republic, Denmark, Estonia, Finland, France, } \\
\text { Germany, Greece, Iceland, Ireland, Israel, Italy, Japan, Korea Republic, Latvia, } \\
\text { Lithuania, Luxembourg, Malta, The Netherlands, New Zealand, Norway, Portugal, } \\
\text { Singapore, Slovak Republic, Slovenia, Spain, Sweden, Switzerland, United Kingdom, } \\
\text { United States. }\end{array}$ \\
\hline
\end{tabular}

Note: The main criteria used by the International Monetary Fund to classify the world into advanced economies, emerging market and developing economies are (1) per capita income level, (2) export diversification — thus, so oil exporters that have high per capita GDP would not make the advanced classification because around $70 \%$ of its exports are oil; and (3) degree of integration in the global financial system. 
Appendix 2: Definition of the explanatory variables and data sources

\begin{tabular}{|c|c|c|}
\hline Variable & Description & Source \\
\hline Real growth rate $\left(g_{t}\right)$ & Growth rate of real per capita GDP (annual \%) & World Development Indicators (World Bank) \\
\hline Level of Output $\left(y_{t}\right)$ & Per capita Gross domestic product at 2010 market prices & World Development Indicators (World Bank) \\
\hline Public debt-to-GDP ratio $\left(d_{t}\right)$ & Ratio of public debt to GDP & World Development Indicators (World Bank) \\
\hline Population growth $\left(P O P G R_{t}\right)$ & Population growth (annual \%) & World Development Indicators (World Bank) \\
\hline GCF-to-GDP ratio $\left(G C F_{t}\right)$ & Absolute sum of exports and imports over GDP & World Development Indicators (World Bank) \\
\hline Openness $\left(\mathrm{OPEN}_{t}\right)$ & Inflation as measured by the consumer price index \\
(annual \%) & World Development Indicators (World Bank), \\
\hline Inflation $\left(I N F_{t}\right)$ &
\end{tabular}




\section{Appendix 3}

\begin{tabular}{|c|c|c|c|}
\hline Variable & & Description & Source \\
\hline \multirow{4}{*}{$\begin{array}{l}\qquad\left(G Q I_{t}\right) \\
\text { This is an average } \\
\text { of the value of } \\
\text { the following four } \\
\text { indicators, } \\
\text { rescaled in order } \\
\text { that it lies } \\
\text { between zero and } \\
\text { one. }\end{array}$} & $\begin{array}{l}\text { Government } \\
\text { effectiveness } \\
\left(G E_{t}\right)\end{array}$ & $\begin{array}{l}\text { Reflects perceptions of the quality of } \\
\text { public services, the quality of the civil } \\
\text { service and the degree of its } \\
\text { independence from political pressures, } \\
\text { the quality of policy formulation and } \\
\text { implementation, and the credibility of } \\
\text { the government's commitment to such } \\
\text { policies. }\end{array}$ & $\begin{array}{c}\text { The Worldwide Governance } \\
\text { Indicators } \\
\text { (World Bank) }\end{array}$ \\
\hline & $\begin{array}{l}\text { Regulatory } \\
\text { Quality } \\
\left(R Q_{t}\right)\end{array}$ & $\begin{array}{l}\text { Reflects perceptions of the ability of } \\
\text { the government to formulate and } \\
\text { implement sound policies and } \\
\text { regulations that permit and promote } \\
\text { private sector development. }\end{array}$ & $\begin{array}{c}\text { The Worldwide Governance } \\
\text { Indicators } \\
\text { (World Bank) }\end{array}$ \\
\hline & $\begin{array}{l}\text { Rule of law } \\
\qquad\left(R L_{t}\right)\end{array}$ & $\begin{array}{l}\text { Reflects perceptions of the extent to } \\
\text { which agents have confidence in and } \\
\text { abide by the rules of society, and in } \\
\text { particular the quality of contract } \\
\text { enforcement, property rights, the } \\
\text { police, and the courts, as well as the } \\
\text { likelihood of crime and violence. }\end{array}$ & $\begin{array}{c}\text { The Worldwide Governance } \\
\text { Indicators } \\
\text { (World Bank) }\end{array}$ \\
\hline & $\begin{array}{l}\text { Control of } \\
\text { corruption } \\
\quad\left(C C_{t}\right)\end{array}$ & $\begin{array}{l}\text { Reflects perceptions of the extent to } \\
\text { which public power is exercised for } \\
\text { private gain, including both petty and } \\
\text { grand forms of corruption, as well as } \\
\text { "capture" of the state by elites and } \\
\text { private interests. }\end{array}$ & $\begin{array}{c}\text { The Worldwide Governance } \\
\text { Indicators } \\
\text { (World Bank) }\end{array}$ \\
\hline $\begin{array}{c}\left(D Q P D_{t}\right) \\
\text { Dummy variable } \\
\text { that takes values } \\
1 \text { to } 4 \\
\text { corresponding to } \\
\text { low, low-middle, } \\
\text { upper-middle, and } \\
\text { high indebted } \\
\text { countries }\end{array}$ & $\begin{array}{l}\text { Public Debt- } \\
\text { to-GDP } \\
\left(P U B D E B T_{t}\right. \\
\left.\text { or } d_{t}\right)\end{array}$ & Ratio of public debt over GDP & $\begin{array}{l}\text { World Development } \\
\text { Indicators } \\
\text { (World Bank) }\end{array}$ \\
\hline $\begin{array}{c}\left(D Q P R D_{t}\right) \\
\text { Dummy variable } \\
\text { that takes values } \\
1 \text { to } 4 \\
\text { corresponding to } \\
\text { low, low-middle, } \\
\text { upper-middle, and } \\
\text { high indebted } \\
\text { countries }\end{array}$ & $\begin{array}{l}\text { Private Debt- } \\
\text { to-GDP } \\
\left(P R D E B T_{t}\right)\end{array}$ & $\begin{array}{l}\text { This variable is calculated as the sum } \\
\text { of two components: (1) bank loans to } \\
\text { domestic households and nonfinancial } \\
\text { corporations, drawn from the IMF's } \\
\text { Standardized Reporting Forms (SRFs) } \\
\text { and International Financial Statistics } \\
\text { (IFS) and (2) the outstanding stock of } \\
\text { debt securities issued (on the domestic } \\
\text { and international markets) by non- } \\
\text { financial corporations, calculated } \\
\text { based on securities issuance data from } \\
\text { Dealogic database. Data are in } \\
\text { percentage of GDP. }\end{array}$ & $\begin{array}{c}\text { Global Debt Database } \\
\text { (International Monetary } \\
\text { Fund) }\end{array}$ \\
\hline $\begin{array}{c}\left(S T D_{t}\right) \\
\text { Debt maturity }\end{array}$ & & $\begin{array}{l}\text { Short term debt expressed as } \\
\text { percentage of total external debt. }\end{array}$ & $\begin{array}{c}\text { World Development } \\
\text { Indicators (World Bank) and } \\
\text { Coordinated Portfolio } \\
\text { Investment Survey, CPIS } \\
\text { (IMF) }\end{array}$ \\
\hline
\end{tabular}




\section{Appendix 4}

\begin{tabular}{|c|c|c|}
\hline Variable & Description & Source \\
\hline $\begin{array}{l}\text { General Public } \\
\text { Services } \\
\left(G F 01_{t}\right)\end{array}$ & $\begin{array}{l}\text { Executive and legislative organs, financial and } \\
\text { fiscal affairs, external affairs; foreign } \\
\text { economic aid; general services; basic research; } \\
\text { R\&D related to general public services; } \\
\text { general public services not else classified } \\
\text { (n.e.c.); public debt transactions, transfers of a } \\
\text { general character between different levels of } \\
\text { government. }\end{array}$ & $\begin{array}{l}\text { Government Financial Statistics } \\
\text { (International Monetary Fund) }\end{array}$ \\
\hline $\begin{array}{l}\text { Defence } \\
\left(G F 02_{t}\right)\end{array}$ & $\begin{array}{l}\text { Military defence; civil defence; foreign military } \\
\text { aid, R\&D related to defence; defence n.e.c. }\end{array}$ & $\begin{array}{l}\text { Government Financial Statistics } \\
\text { (International Monetary Fund) }\end{array}$ \\
\hline $\begin{array}{l}\text { Public order and } \\
\text { safety } \\
\left(G F 03_{t}\right)\end{array}$ & $\begin{array}{l}\text { Police services; fire-protection services; law } \\
\text { courts; prisons; R\&D related to public order } \\
\text { and safety; public order and safety n.e.c. }\end{array}$ & $\begin{array}{l}\text { Government Financial Statistics } \\
\text { (International Monetary Fund) }\end{array}$ \\
\hline $\begin{array}{l}\text { Economic affairs } \\
\qquad\left(\mathrm{GFO} 4_{t}\right)\end{array}$ & $\begin{array}{l}\text { General economic, commercial and labour } \\
\text { affairs; agriculture, forestry; fishing and } \\
\text { hunting; fuel and energy; mining, } \\
\text { manufacturing and construction; transport; } \\
\text { communication; other industries, R\&D } \\
\text { related to economic affairs; economic affairs } \\
\text { n.e.c. }\end{array}$ & $\begin{array}{l}\text { Government Financial Statistics } \\
\text { (International Monetary Fund) }\end{array}$ \\
\hline $\begin{array}{l}\text { Environment } \\
\text { protection } \\
\left(G F 05_{t}\right)\end{array}$ & $\begin{array}{l}\text { Waste management; water waste } \\
\text { management; pollution abatement; protection } \\
\text { of biodiversity and landscape; R\&D related to } \\
\text { environmental protection. }\end{array}$ & $\begin{array}{l}\text { Government Financial Statistics } \\
\text { (International Monetary Fund) }\end{array}$ \\
\hline $\begin{array}{l}\text { Housing and } \\
\text { community amenities } \\
\left(\mathrm{GFO} \sigma_{t}\right)\end{array}$ & $\begin{array}{l}\text { Housing development; community } \\
\text { development; water supply; street lighting; } \\
\text { R\&D related to housing and community } \\
\text { amenities; housing and community amenities } \\
\text { n.e.c. }\end{array}$ & $\begin{array}{l}\text { Government Financial Statistics } \\
\text { (International Monetary Fund) }\end{array}$ \\
\hline $\begin{array}{l}\text { Health } \\
(\text { GF07t) }\end{array}$ & $\begin{array}{l}\text { Medical products, appliances and equipment; } \\
\text { outpatient services; hospital services; public } \\
\text { health services; R\&D related to health; health } \\
\text { n.e.c. }\end{array}$ & $\begin{array}{l}\text { Government Financial Statistics } \\
\text { (International Monetary Fund) }\end{array}$ \\
\hline $\begin{array}{l}\text { Recreation, culture } \\
\text { and religion } \\
\quad\left(G F 08_{t}\right)\end{array}$ & $\begin{array}{l}\text { Recreational and sporting services; cultural } \\
\text { services; broadcasting and publishing services; } \\
\text { religious and other community services, R\&D } \\
\text { related to recreation, culture and religion; } \\
\text { recreation; culture and religion n.e.c. }\end{array}$ & $\begin{array}{l}\text { Government Financial Statistics } \\
\text { (International Monetary Fund) }\end{array}$ \\
\hline $\begin{array}{l}\text { Education } \\
\left(G F 09_{t}\right)\end{array}$ & $\begin{array}{l}\text { Pre-primary, primary, secondary and tertiary } \\
\text { education, post-secondary non-tertiary } \\
\text { education, education non definable by level, } \\
\text { subsidiary services to education, R\&D; n.e.c. }\end{array}$ & $\begin{array}{l}\text { Government Financial Statistics } \\
\text { (International Monetary Fund) }\end{array}$ \\
\hline $\begin{array}{l}\text { Social protection } \\
\qquad\left(G F 10_{t}\right)\end{array}$ & $\begin{array}{l}\text { Sickness and disability; old age; survivors; } \\
\text { family and children; unemployment; housing; } \\
\text { R\&D; social protection and social exclusion } \\
\text { n.e.c. }\end{array}$ & $\begin{array}{l}\text { Government Financial Statistics } \\
\text { (International Monetary Fund) }\end{array}$ \\
\hline
\end{tabular}

Note: Expenditure in the different COFOG is presented as percent of GDP. 


\section{Appendix 5. Brief description of the GFE estimator}

The GFE estimation introduces time-varying grouped patterns of heterogeneity in linear panel data models important to establish whether the relationship under study is heterogeneous across groups of countries. The estimator minimizes a least squares criterion with respect to all possible groupings of the cross-sectional units. The most appealing feature of this approach is that group membership is left unrestricted. The estimator is suitable for $N$ big and $T$ small and it is consistent, since both dimensions of the panel tend to infinity.

One of the most common approaches to model unobserved heterogeneity in panel data is the use of time-invariant fixed-effects. This standard approach is sometimes subject to poorly estimated elasticities when there are errors in the data or when the explanatory variables vary slowly over time. Moreover, it is restrictive in that unobserved heterogeneity is assumed to be constant over time. The GFE introduces clustered time patterns of unobserved heterogeneity that are common within groups of countries. Both the groupspecific time patterns and group membership are estimated from the data. The relationship between observed variables and the unobserved group heterogeneity is unrestricted, allowing for the existence of correlations that would create omitted variable bias in standard fixed-effects estimates.

Our benchmark specification is a linear model that explains economic growth, $g_{\text {it }}$, with grouped patterns of heterogeneity and takes the form:

$$
\ln g_{i t}=x_{i t}^{\prime} \beta+\gamma_{g_{i} t}+u_{i t}
$$

where $x_{i t}^{\prime}$ are the covariates that are assumed to be contemporaneously uncorrelated with the error term, $u_{i t}$, but are allowed to be arbitrarily correlated with group-specific unobserved heterogeneity, $\gamma_{g_{i}}$. The countries in the same group share the same time profile and the number of groups is to be decided or estimated by the researcher and group membership remains constant over time.

In essence, countries that have similar time profiles of growth - net of the explanatory variables - are grouped together. The main underlying assumption is that group membership remains constant over time. 
The model can be easily modified to allow for additive time-invariant fixed effects, which is our preferred specification ${ }^{37}$. We apply the within transformation to the dependent and independent variables and estimate the model with variables in deviations with respect to the within-mean. The new transformed variables are denoted as $\ddot{x}_{i t}=\left(x_{i t}-\right.$ $\left.\bar{x}_{i}\right)$ and $\ddot{g}_{i t}=\left(g_{i t}-\bar{g}_{i}\right)$, etc.

The GFE in model (A5.1) is the outcome of the minimization of the following expression:

$$
(\hat{\beta}, \hat{\gamma}, \hat{\alpha})=\operatorname{argmin}_{(\beta, \gamma, \alpha) \in \Theta \times A^{G T} \times \Gamma_{G}} \sum_{i=1}^{N} \sum_{t=1}^{T}\left(\ddot{g}_{i t}-\ddot{x}_{i t}^{\prime} \beta-\ddot{\gamma}_{g_{i} t}\right)^{2}
$$

where the minimum is taken over all possible groupings $\alpha=\left\{\mathrm{g}_{1}, \ldots, \mathrm{g}_{\mathrm{n}}\right\}$ of the $N$ units into groups, common parameters $\beta$ and group-specific time effects $\gamma$.

An alternative characterization, which is based on concentrated group membership variables, is introduced for computational purposes. Then, the optimal group assignment for each country is given by:

$$
\hat{g}_{i}(\beta, \gamma)=\operatorname{argmin}_{g \in\{1, \ldots, G\}} \sum_{t=1}^{T}\left(\ddot{g}_{i t}-\ddot{x}_{i t}^{\prime} \beta-\ddot{\gamma}_{g_{i} t}\right)^{2}
$$

where the minimum $g$ is chosen in case of a non-unique solution. The GFE estimator of beta and gamma could be expressed as:

$$
(\hat{\beta}, \hat{\gamma})=\operatorname{argmin}_{(\beta, \gamma) \in \Theta \times A}{ }_{i T} \sum_{i=1}^{N} \sum_{t=1}^{T}\left(\ddot{g}_{i t}-\ddot{x}_{i t}^{\prime} \beta-\ddot{\gamma}_{\hat{g}_{i}(\beta, \gamma) t}\right)^{2}
$$

where the GFE estimate of $g_{i}$ is $\hat{g}_{i}(\hat{\beta}, \hat{\gamma})$ and the group probabilities are unrestricted and individual-specific.

There are two algorithms available to minimize expression (A5.4). The first one uses a simple iterative strategy and is suitable for small-scale datasets, whereas the second, which exploits recent advances in data clustering, is preferred for larger-scale problems. The former is used in this paper ${ }^{38}$.

\footnotetext{
37 The idea is to control not only for time-variant group-specific heterogeneity, but also for time-invariant countryspecific unobserved heterogeneity.

${ }^{38}$ Very similar results were obtained using the second procedure.
} 


\section{Appendix 6. Brief description of Bring (1994)'s new standardize regression coefficients.}

Consider an estimated regression equation of $y$ on $x_{1}, x_{2}, \ldots, x_{k}$ :

$$
y=\alpha+\beta_{1} x_{1}+\beta_{2} x_{2}{ }^{`} \ldots+\beta_{k} x_{k}+\varepsilon
$$

Traditional standardized regression coefficients can be calculated by first standardizing all variables,

$$
\begin{aligned}
& x_{i}^{*}=\frac{x_{i}-\bar{x}_{i}}{s_{i}}, i=1, \ldots, k \\
& y^{*}=\frac{y-\bar{y}}{s_{y}}
\end{aligned}
$$

where $\bar{x}_{i}$ and $\bar{y}$ are the means of each variable in the sample and $s_{i}$ and $s_{y}$ are the standard deviations, and then estimate( A6.1) by ordinary least squares with the standardized variables, being the regression coefficients in this equation the standardized regression coefficients.

The standardized coefficients are interpreted as the standard deviation change in the dependent variable when the independent variable is changed by one standard deviation, holding all other variables constant. Therefore, instead of comparing changes by one unit as in the usual regression coefficients, the comparison is between changes of standard deviations.

Bring (1994) proposes an alternative way to calculate consistent standardized coefficients using the variance inflation factor (VIF). In this way, when $y$ is regressed on $x_{1}, x_{2}, \ldots, x_{k}$ each independent variable is associated with a VIF:

$$
s_{i}^{*}=\frac{s_{i}}{\sqrt{V I F_{i}}} \sqrt{(n-1) /(n-k)}
$$

Bring (1994) shows although the traditional standardized coefficient is not directly related to the reduction in $R^{2}$ obtained by excluding the variable from the model, the new standardized coefficients are. The reduction in $R^{2}$ is larger when a variable with a larger coefficient is removed compared with the loss if a variable with a smaller coefficient is removed. Therefore, Bring (1994)' proposal is helpful in measuring the relative importance of a given explanatory variable. Indeed, as Afifi and Clarke (1990) contend, a variable's 
standardized coefficient is related to the variable's contribution to the prediction of $y$, and the more a variable contributes to the prediction of $Y$, the more important it is. 


\section{Figure 1: Government debt-to-GDP}

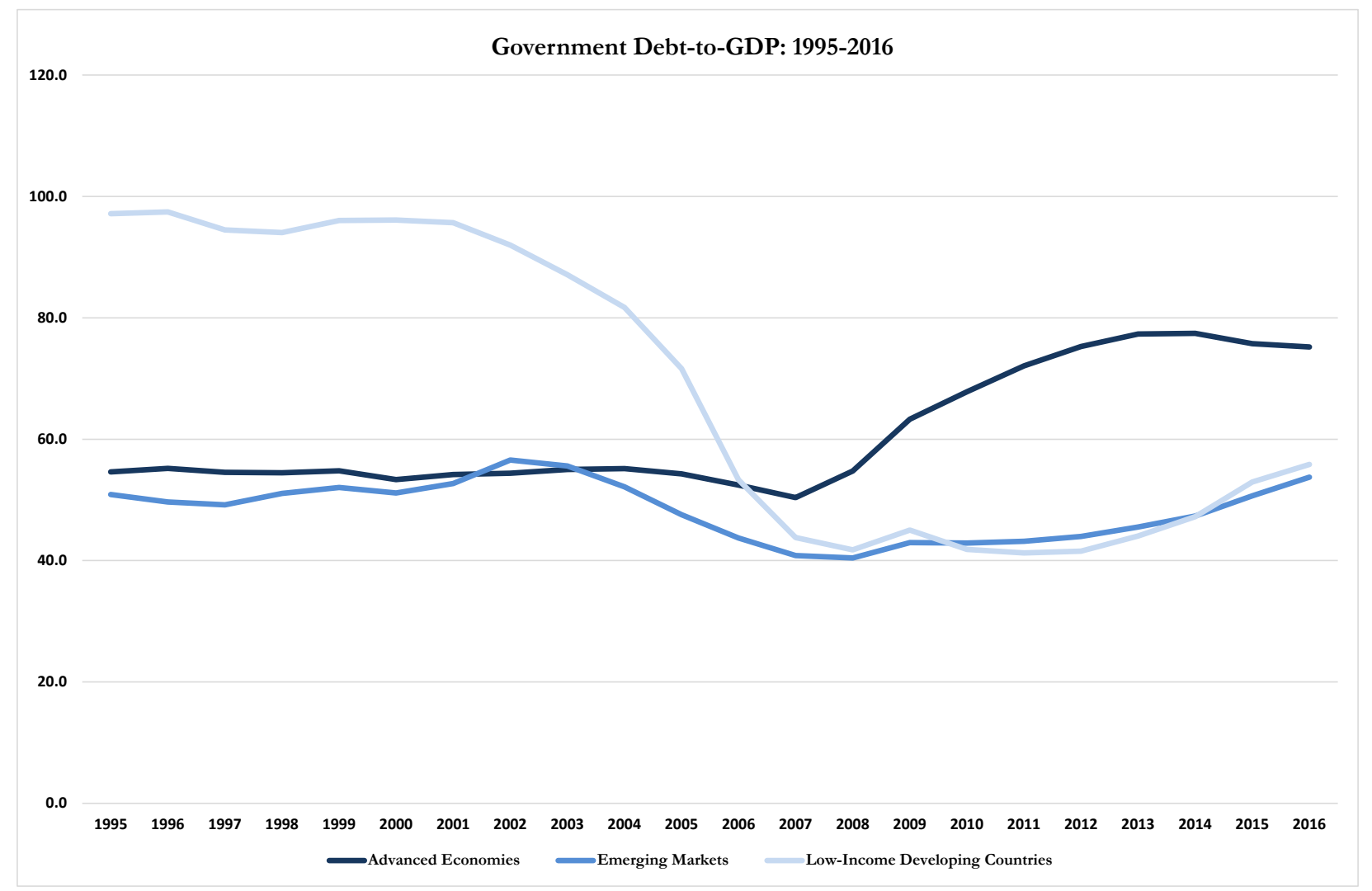

Note: The sample includes 116 countries divided by the International Monetary Fund into advanced, emerging market and low-income developing economies according to: (1) per capita income level, (2) export diversification, and (3) degree of integration into the global financial system. 
Figure 2: Impact of changes in public debt on economic growth by groups of countries

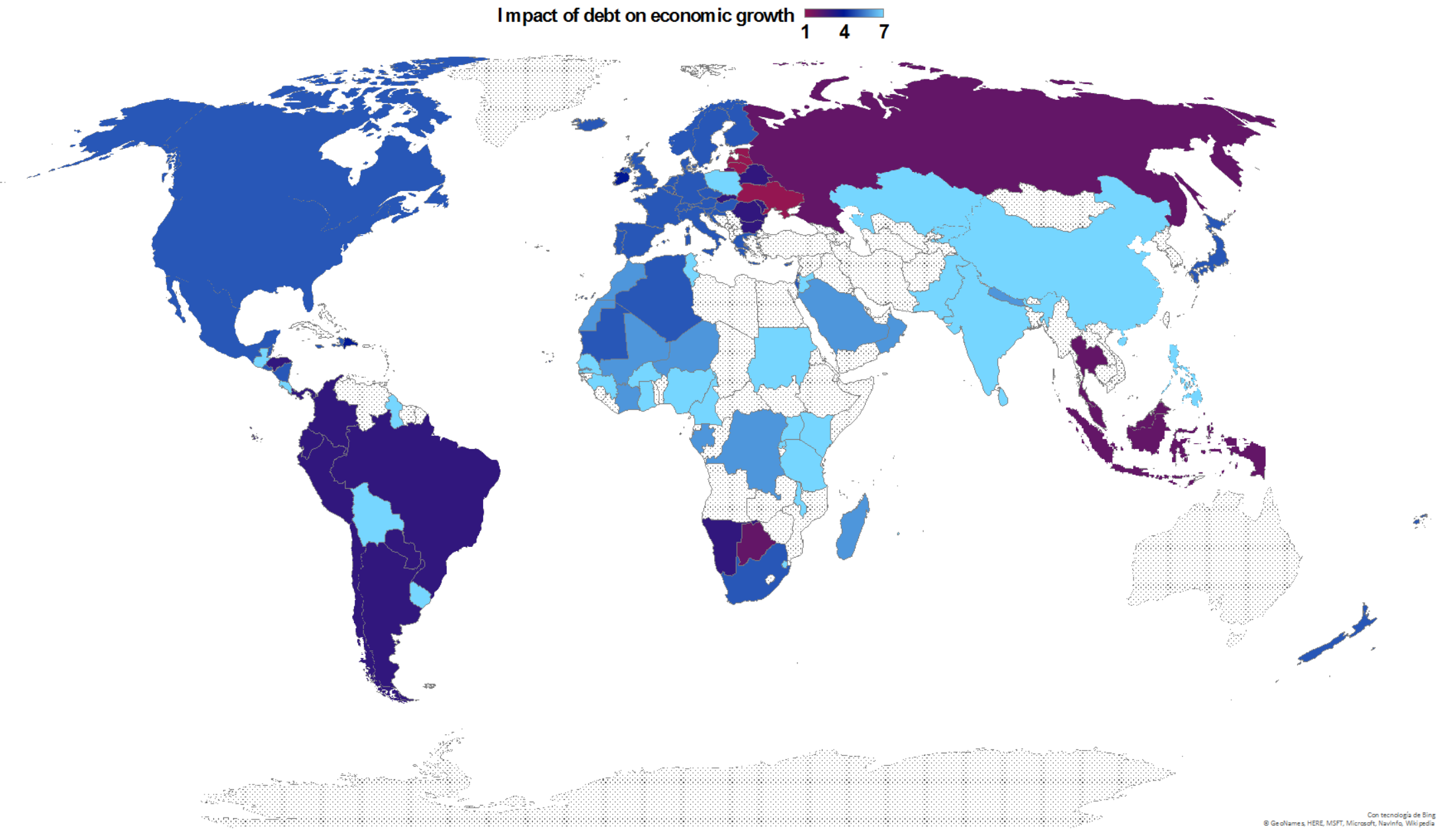


Figure 3: Time-varying coefficients of changes in the public debt-to-GDP ratio on economic growth.

1

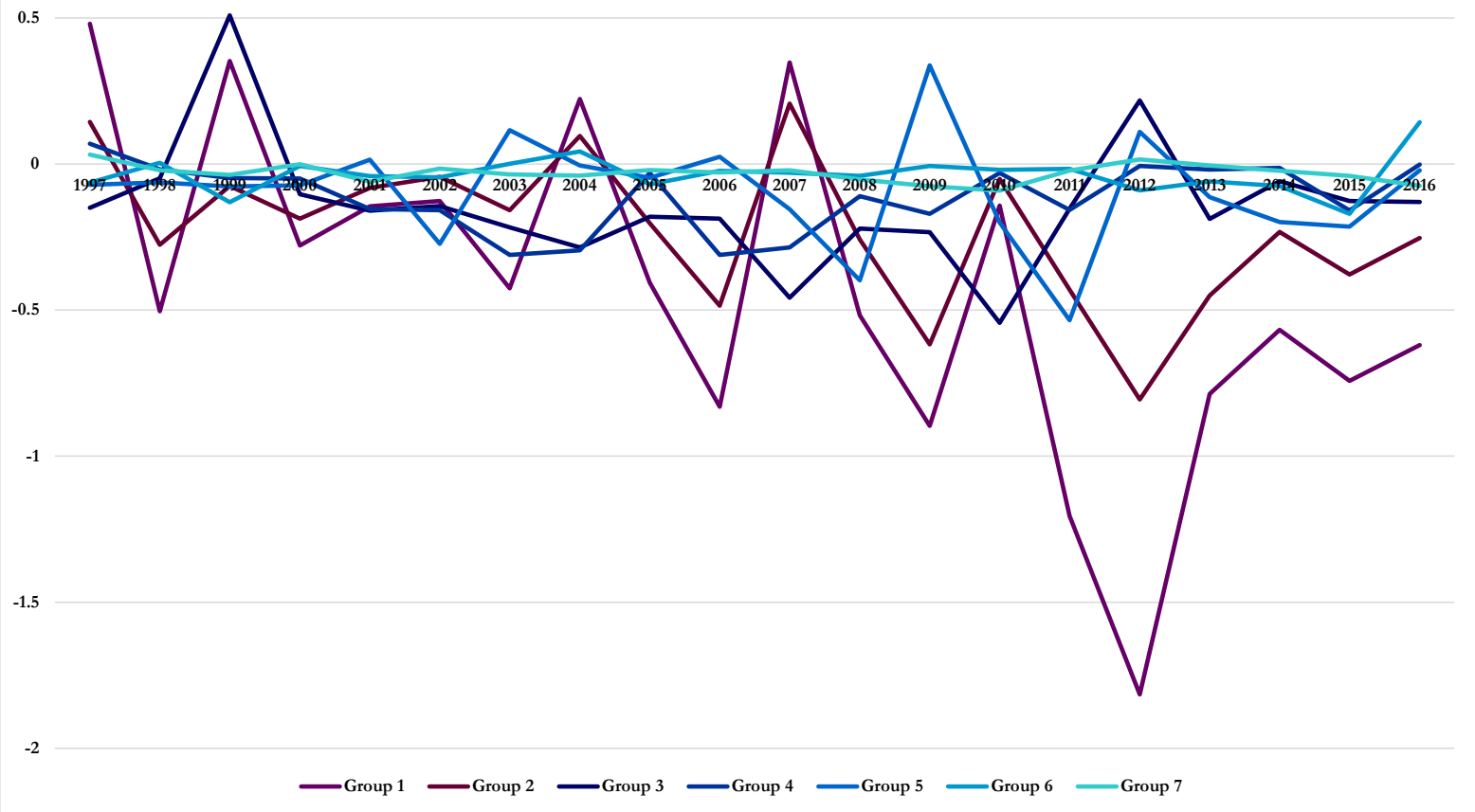


Table 1: Parameter estimates for the benchmark model

\begin{tabular}{|c|c|c|c|}
\hline & OLS & FE & GFE \\
\hline$g_{t-1}$ & $\begin{array}{c}0.290^{* * *} \\
(0.027)\end{array}$ & $\begin{array}{c}0.190^{* * *} \\
(0.018) \\
\end{array}$ & $\begin{array}{c}0.286^{* * *} \\
(0.034)\end{array}$ \\
\hline$\Delta d_{t}$ & $\begin{array}{c}-0.093 * * \\
(0.011)\end{array}$ & $\begin{array}{c}-0.078^{* * *} \\
(0.007)\end{array}$ & $\begin{array}{c}-0.072 * * \\
(0.011)\end{array}$ \\
\hline$\Delta H K_{t}$ & $\begin{array}{c}0.155 \\
(0.180)\end{array}$ & $\begin{array}{c}0.167 \\
(0.163)\end{array}$ & $\begin{array}{l}0.343^{*} \\
(0.169)\end{array}$ \\
\hline$\triangle O P E N_{t}$ & $\begin{array}{c}0.050 * * * \\
(0.010)\end{array}$ & $\begin{array}{c}0.005 \\
(0.007)\end{array}$ & $\begin{array}{c}0.003 \\
(0.008)\end{array}$ \\
\hline$I N F_{t}$ & $\begin{array}{c}-0.007 * * \\
(0.003) \\
\end{array}$ & $\begin{array}{c}-0.011 * * * \\
(0.002)\end{array}$ & $\begin{array}{c}-0.008^{* *} \\
(0.003)\end{array}$ \\
\hline$P O P G R_{t}$ & $\begin{array}{c}-0.407 * * * \\
(0.058)\end{array}$ & $\begin{array}{c}-0.755^{* * *} \\
(0.108)\end{array}$ & $\begin{array}{c}-0.651 * * * \\
(0.065)\end{array}$ \\
\hline$G C F_{t}$ & $\begin{array}{c}0.075^{* * *} \\
(0.010)\end{array}$ & $\begin{array}{c}0.113^{* * *} \\
(0.012)\end{array}$ & $\begin{array}{c}0.075^{* * *} \\
(0.012)\end{array}$ \\
\hline Constant & $\begin{array}{c}0.163 \\
(0.252)\end{array}$ & $\begin{array}{c}1.035^{* *} \\
(0.300)\end{array}$ & $\begin{array}{c}2.112^{* * *} \\
(0.823)\end{array}$ \\
\hline Country FE & No & Yes & No \\
\hline Group FE & No & No & Yes \\
\hline Year FE & No & Yes & Yes \\
\hline Group-year FE & No & No & Yes \\
\hline Time trend & Yes & No & No \\
\hline $\mathbf{N}$ & 2435 & 2435 & 2435 \\
\hline Adjusted $\mathbf{R}^{2}$ & 0.265 & 0.265 & 0.544 \\
\hline BIC & 12242.68 & 11753.10 & 11746.57 \\
\hline RMSE & 2.961 & 2.675 & 2.331 \\
\hline
\end{tabular}

Notes: heterogeneous effects, given by equations (2) and (4) respectively.

OLS, FE and GFE denote, respectively, results from pooled-OLS, fixed-effects and grouped fixed effect estimation methods.

The dependent variable is $g_{t}$, the growth rate of real per capita GDP. $\Delta d t_{i}$ is variation in the public debt-to-GDP ratio, $\triangle H K_{t}$ is the variation of human capital, $\triangle O P E N_{t}$ is the variation in openness to trade, $I N F_{t}$ is the GDP deflator inflation rate, $P O P G R_{t}$ is the population growth rate and $G C F_{t}$ is the ratio of gross capital formation to GDP.

Robust standard errors in brackets. GFE results obtained with algorithm 1, described in Appendix 5.

*** $\mathrm{p}<0.01, * * \mathrm{p}<0.05, * \mathrm{p}<0.1$ 
Table 2: Composition of detected groups ordered according to the debt coefficient

\begin{tabular}{|l|l|l|l|l|l|}
\hline GROUP 1: & Region & $\begin{array}{l}\text { Income } \\
\text { group }\end{array}$ & Other classifications & $\begin{array}{l}\text { Public } \\
\text { indebtedness }\end{array}$ & $\begin{array}{l}\text { Private } \\
\text { indebtedness }\end{array}$ \\
\hline Estonia & Europe \& Central Asia & AE & OECD; EMU & LI & HI \\
Latvia & Europe \& Central Asia & AE & OECD; EMU & LI & LMI \\
Lithuania & Europe \& Central Asia & AE & EMU & LI & UMI \\
Ukraine & Europe \& Central Asia & EM & & LMI & UMI \\
\hline
\end{tabular}

\begin{tabular}{|l|l|l|l|l|l|}
\hline GROUP 2: & Region & $\begin{array}{l}\text { Income } \\
\text { group }\end{array}$ & Other classifications & $\begin{array}{l}\text { Public } \\
\text { indebtedness }\end{array}$ & $\begin{array}{l}\text { Private } \\
\text { indebtedness }\end{array}$ \\
\hline Korea, Rep. & East Asia \& Pacific & AE & G20; OECD & LI & HI \\
Singapore & East Asia \& Pacific & AE & & HI & HI \\
Indonesia & East Asia \& Pacific & EM & G20; Oil Exporter & LI & LMI \\
Malaysia & East Asia \& Pacific & EM & & UMI & HI \\
Thailand & East Asia \& Pacific & EM & & LMI & HMI \\
Russia & Europe \& Central Asia & EM & G20; Oil Exporter & LI & UMI \\
Botswana & Sub-Saharan Africa & EM & & LI & LI \\
\hline
\end{tabular}

\begin{tabular}{|l|l|l|l|l|l|}
\hline GROUP 3: & Region & $\begin{array}{l}\text { Income } \\
\text { group }\end{array}$ & Other classifications & $\begin{array}{l}\text { Public } \\
\text { indebtedness }\end{array}$ & $\begin{array}{l}\text { Private } \\
\text { indebtedness }\end{array}$ \\
\hline Moldova & Europe \& Central Asia & LIDC & & LMI & LI \\
Belarus & Europe \& Central Asia & EM & G20; OECD & LI & \\
Turkey & Europe \& Central Asia & EM & LMI & LMI \\
Romania & Europe \& Central Asia & EM & EU & LI & LMI \\
Bulgaria & Europe \& Central Asia & EM & EU & LI & UMI \\
Slovak Rep. & Europe \& Central Asia & AE & OECD; EMU & LMI & UMI \\
Brazil & Latin America \& Caribbean & EM & G20 & HMI & HMI \\
Argentina & Latin America \& Caribbean & EM & G20 & LMI & LMI \\
Chile & Latin America \& Caribbean & EM & OECD & LI & UMI \\
Colombia & Latin America \& Caribbean & EM & & LMI & LMI \\
Ecuador & Latin America \& Caribbean & EM & OPEC & UMI & LMI \\
Panama & Latin America \& Caribbean & EM & & UMI & \\
Paraguay & Latin America \& Caribbean & EM & & LI & LMI \\
Peru & Latin America \& Caribbean & EM & & LMI & LMI \\
Honduras & Latin America \& Caribbean & LIDC & & UMI & LMI \\
Namibia & Sub-Saharan Africa & EM & & LI & \\
\hline
\end{tabular}

\begin{tabular}{|c|c|c|c|c|c|}
\hline GROUP 4: & Region & $\begin{array}{l}\text { Income } \\
\text { gtoup }\end{array}$ & Other classifications & $\begin{array}{l}\text { Public } \\
\text { indebtedness }\end{array}$ & $\begin{array}{l}\text { Private } \\
\text { indebtedness }\end{array}$ \\
\hline Ireland & Europe \& Central Asia & $\mathrm{AE}$ & OECD; EMU & $\mathrm{HI}$ & $\mathrm{HI}$ \\
\hline Luxembourg & Europe \& Central Asia & $\mathrm{AE}$ & OECD; EMU & LI & HI \\
\hline Malta & Middle East \& North Africa & $\mathrm{AE}$ & EMU & UMI & HI \\
\hline Dominican & Latin America \& Caribbean & EM & & LI & \\
\hline Rep. & & & & & LMI \\
\hline Seychelles & Sub-Saharan Africa & EM & & $\mathrm{HI}$ & \\
\hline Cape Verde & Sub-Saharan Africa & LIDC & & $\mathrm{HI}$ & LMI \\
\hline
\end{tabular}

\begin{tabular}{|l|l|l|l|l|l|}
\hline GROUP 5: & Region & Income & Other classifications & Public & Private \\
\hline \multicolumn{6}{|c|}{39}
\end{tabular}




\begin{tabular}{|c|c|c|c|c|c|}
\hline & & group & & indebtedness & indebtedness \\
\hline Austria & Europe \& Central Asia & $\mathrm{AE}$ & OECD; EMU & UMI & HI \\
\hline Belgium & Europe \& Central Asia & $\mathrm{AE}$ & OECD; EMU & $\mathrm{HI}$ & HI \\
\hline Cyprus & Europe \& Central Asia & $\mathrm{AE}$ & EMU & UMI & HI \\
\hline Finland & Europe \& Central Asia & $\mathrm{AE}$ & OECD; EMU & LMI & HI \\
\hline France & Europe \& Central Asia & $\mathrm{AE}$ & G20; OECD; EMU & LMI & HI \\
\hline Germany & Europe \& Central Asia & $\mathrm{AE}$ & G20; OECD; EMU & UMI & UMI \\
\hline Greece & Europe \& Central Asia & $\mathrm{AE}$ & OECD; EMU & $\mathrm{HI}$ & UMI \\
\hline Italy & Europe \& Central Asia & $\mathrm{AE}$ & G20; OECD; EMU & HI & UMI \\
\hline Netherlands & Europe \& Central Asia & $\mathrm{AE}$ & OECD; EMU & UMI & HI \\
\hline Portugal & Europe \& Central Asia & $\mathrm{AE}$ & OECD; EMU & UMI & $\mathrm{HI}$ \\
\hline Slovenia & Europe \& Central Asia & $\mathrm{AE}$ & EMU & LI & UMI \\
\hline Spain & Europe \& Central Asia & $\mathrm{AE}$ & OECD; EMU & UMI & HI \\
\hline Czech Rep. & Europe \& Central Asia & $\mathrm{AE}$ & OECD; EU & LI & UMI \\
\hline Denmark & Europe \& Central Asia & $\mathrm{AE}$ & OECD; EU & LMI & $\mathrm{HI}$ \\
\hline Sweden & Europe \& Central Asia & $\mathrm{AE}$ & OECD; EU & LMI & HI \\
\hline United Kingdom & Europe \& Central Asia & $\mathrm{AE}$ & G20; OECD; EU & LMI & $\mathrm{HI}$ \\
\hline Croatia & Europe \& Central Asia & EM & $\mathrm{EU}$ & LMI & UMI \\
\hline Hungary & Europe \& Central Asia & EM & OECD; EU & UMI & UMI \\
\hline Iceland & Europe \& Central Asia & $\mathrm{AE}$ & OECD & LMI & $\mathrm{HI}$ \\
\hline Norway & Europe \& Central Asia & $\mathrm{AE}$ & OECD; Oil Exporter & LMI & HI \\
\hline Switzerland & Europe \& Central Asia & $\mathrm{AE}$ & OECD & UMI & HI \\
\hline Canada & North America & $\mathrm{AE}$ & G20; OECD & $\mathrm{HI}$ & HI \\
\hline United States & North America & $\mathrm{AE}$ & G20; OECD & UMI & HI \\
\hline Japan & East Asia \& Pacific & $\mathrm{AE}$ & G20; OECD & $\mathrm{HI}$ & HI \\
\hline New Zealand & East Asia \& Pacific & $\mathrm{AE}$ & OECD & LMI & HI \\
\hline Fiji & East Asia \& Pacific & EM & & LMI & \\
\hline Bahamas & Latin America \& Caribbean & EM & & LI & HI \\
\hline Barbados & Latin America \& Caribbean & EM & & HI & \\
\hline Belize & Latin America \& Caribbean & $\mathrm{EM}$ & & HI & \\
\hline El Salvador & Latin America \& Caribbean & EM & & LMI & LMI \\
\hline Jamaica & Latin America \& Caribbean & EM & & $\mathrm{HI}$ & UMI \\
\hline Mexico & Latin America \& Caribbean & $\mathrm{EM}$ & G20; OECD; Oil Exporter & LMI & LMI \\
\hline Nicaragua & Latin America \& Caribbean & LIDC & & $\mathrm{HI}$ & LMI \\
\hline Haiti & Latin America \& Caribbean & LIDC & & LMI & LI \\
\hline Israel & Middle East \& North Africa & $\mathrm{AE}$ & OECD & UMI & UMI \\
\hline Algeria & Middle East \& North Africa & EM & OPEC & LI & LI \\
\hline Iran & Middle East \& North Africa & EM & OPEC & LI & LMI \\
\hline South Africa & Sub-Saharan Africa & EM & G20 & LMI & UMI \\
\hline Comoros & Sub-Saharan Africa & LIDC & & $\mathrm{HI}$ & LI \\
\hline Mauritania & Sub-Saharan Africa & LIDC & & $\mathrm{HI}$ & LMI \\
\hline
\end{tabular}

\begin{tabular}{|l|l|l|l|l|l|}
\hline GROUP 6: & Region & $\begin{array}{l}\text { Income } \\
\text { group }\end{array}$ & Other classifications & $\begin{array}{l}\text { Public } \\
\text { indebtedness }\end{array}$ & $\begin{array}{l}\text { Private } \\
\text { indebtedness }\end{array}$ \\
\hline Congo Rep. & Sub-Saharan Africa & LIDC & OPEC & HI & LI \\
Congo, D.R. & Sub-Saharan Africa & LIDC & & HI & LI \\
Côte d'Ivoire & Sub-Saharan Africa & LIDC & & HI & LI \\
Gambia & Sub-Saharan Africa & LIDC & & UMI & LI \\
Madagascar & Sub-Saharan Africa & LIDC & & UMI & LI \\
Mali & Sub-Saharan Africa & LIDC & & LMI & LI \\
Niger & Sub-Saharan Africa & LIDC & & HI & LI \\
Gabon & Sub-Saharan Africa & EM & OPEC & UMI & \\
Morocco & Middle East \& North Africa & EM & & UMI & UMI \\
Oman & Middle East \& North Africa & EM & Oil Exporter & LI & UMI \\
Saudi Arabia & Middle East \& North Africa & EM & G20; OPEC & LI & LMI \\
Nepal & South Asia & LIDC & & UMI & LMI \\
\hline
\end{tabular}




\begin{tabular}{|c|c|c|c|c|c|}
\hline GROUP 7: & Region & $\begin{array}{l}\text { Income } \\
\text { group }\end{array}$ & Other classifications & $\begin{array}{l}\text { Public } \\
\text { indebtedness }\end{array}$ & \begin{tabular}{|l|} 
Private \\
indebtedness
\end{tabular} \\
\hline Burkina Faso & Sub-Saharan Africa & LIDC & & LMI & LI \\
\hline Cameroon & Sub-Saharan Africa & LIDC & Oil Exporter & HI & LI \\
\hline Ghana & Sub-Saharan Africa & LIDC & & UMI & LI \\
\hline Guinea & Sub-Saharan Africa & LIDC & & UMI & LI \\
\hline Kenya & Sub-Saharan Africa & LIDC & & UMI & LMI \\
\hline Malawi & Sub-Saharan Africa & LIDC & & UMI & LI \\
\hline Nigeria & Sub-Saharan Africa & LIDC & OPEC & LI & LI \\
\hline Rwanda & Sub-Saharan Africa & LIDC & & $\mathrm{HI}$ & LI \\
\hline Sudan & Sub-Saharan Africa & LIDC & Oil Exporter & $\mathrm{HI}$ & LI \\
\hline Tanzania & Sub-Saharan Africa & LIDC & & LMI & LI \\
\hline Uganda & Sub-Saharan Africa & LIDC & & UMI & LI \\
\hline Eswatini & Sub-Saharan Africa & $\mathrm{EM}$ & & LI & \\
\hline Mauritius & Sub-Saharan Africa & EM & & UMI & UMI \\
\hline Senegal & Sub-Saharan Africa & $\mathrm{EM}$ & & LI & LI \\
\hline Bahrain & Middle East \& North Africa & EM & & LI & UMI \\
\hline Egypt & Middle East \& North Africa & EM & Oil Exporter & HI & LMI \\
\hline Jordan & Middle East \& North Africa & EM & & HI & UMI \\
\hline Tunisia & Middle East \& North Africa & EM & & UMI & \\
\hline Bolivia & Latin America \& Caribbean & EM & Oil Exporter & LMI & \\
\hline Costa Rica & Latin America \& Caribbean & EM & & LMI & LMI \\
\hline Guatemala & Latin America \& Caribbean & EM & & LI & LMI \\
\hline Uruguay & Latin America \& Caribbean & EM & & UMI & LMI \\
\hline Guyana & Latin America \& Caribbean & LIDC & & $\mathrm{HI}$ & LMI \\
\hline India & South Asia & EM & G20 & UMI & LMI \\
\hline Pakistan & South Asia & EM & & UMI & LMI \\
\hline Sri Lanka & South Asia & EM & & HI & LMI \\
\hline China & East Asia \& Pacific & EM & G20 & LI & UMI \\
\hline Philippines & East Asia \& Pacific & EM & & UMI & LMI \\
\hline Kazakhstan & Europe \& Central Asia & EM & Oil Exporter & LI & LMI \\
\hline Kyrgyz & Europe \& Central Asia & LIDC & & HI & LI \\
\hline Poland & Europe \& Central Asia & EM & OECD; EU & LMI & LMI \\
\hline
\end{tabular}

Note:

Regarding income groups, for operational and analytical purposes, economies are divided among three groups according to the International Monetary Fund (IMF) classification. Therefore, AE, EM and LIDC stand for Advanced Economies, Emerging Market Economies and Low-Income Developing countries. The main criteria used by the IMF to classify the world into advanced economies, emerging market and developing economies are (1) per capita income level, (2) export diversification - so oil exporters that have high per capita GDP would not make the advanced classification because around $70 \%$ of its exports are oil; and (3) degree of integration into the global financial system.

As for other classifications: OECD: Organisation for Economic Cooperation and Development; EU: European Union; EMU: European Economic and Monetary Union; OPEC: Organization of the Petroleum Exporting Countries; G20: Group of twenty economies that account for around $90 \%$ of the gross world product.

In relation to relative public and private indebtedness, based on public and private debt-to-GDP ratios, we have classified them as low indebted (LI), lower middle indebted (LMI), upper middle indebted (UMI), and high indebted (HI), the cutoff points between each of the groups being the first, the second and the third quartiles. 
Table 3: Heterogeneous effects by groups, GFE

\begin{tabular}{|c|c|}
\hline & GFE \\
\hline$g_{t-1}$ & $\begin{array}{c}0.173^{* * *} \\
(0.018)\end{array}$ \\
\hline Group1* $\Delta d_{t}$ & $\begin{array}{c}-0.430 * * * \\
(0.050)\end{array}$ \\
\hline Group $2 * \Delta d_{t}$ & $\begin{array}{c}-0.227 * * * \\
(0.041)\end{array}$ \\
\hline Group $3 * \Delta d_{t}$ & $\begin{array}{c}-0.143^{* * * *} \\
(0.016)\end{array}$ \\
\hline Group $4 * \Delta d_{t}$ & $\begin{array}{c}-0.113^{* * *} \\
(0.019)\end{array}$ \\
\hline Group $5^{*} \Delta d_{t}$ & $\begin{array}{c}-0.092 * * * \\
(0.015)\end{array}$ \\
\hline Group $6^{*} \Delta d_{t}$ & $\begin{array}{c}-0.035^{* * *} \\
(0.012)\end{array}$ \\
\hline Group $7 * \Delta d_{t}$ & $\begin{array}{c}-0.031 * * * \\
(0.022)\end{array}$ \\
\hline$\Delta H K_{t}$ & $\begin{array}{l}-0.034 \\
(0.160)\end{array}$ \\
\hline$\triangle O P E N_{t}$ & $\begin{array}{c}0.008 \\
(0.007)\end{array}$ \\
\hline$I N F_{t}$ & $\begin{array}{c}-0.011 * * * \\
(0.002)\end{array}$ \\
\hline$P O P G R_{t}$ & $\begin{array}{c}-0.738^{* * *} \\
(0.011)\end{array}$ \\
\hline$G C F_{t}$ & $\begin{array}{c}0.106^{* * *} \\
(0.012)\end{array}$ \\
\hline Constant & $\begin{array}{c}1.199 * * * \\
(0.383)\end{array}$ \\
\hline $\mathbf{N}$ & 2435 \\
\hline
\end{tabular}

Notes:

The table reports estimated coefficients from the extended model to explore the possibility of heterogeneous effects, given by equation (4), including interactions of the variable $\Delta d_{t}$ with the group indicator variables.

The dependent variable is $g_{t}$, the growth rate of real per capita GDP. $\Delta d_{t}$ is variation in the public debt-to-GDP ratio, $\triangle H K t$ is the variation of human capital, $\triangle O P E N_{t}$ is the variation in openness to trade, INFt is the GDP deflator inflation rate, POPGR $\mathrm{t}_{\mathrm{t}}$ is the population growth rate and $G C F_{t}$ is the ratio of gross capital formation to GDP.

Group 1, Group 2, .., Group 7 are dummy variables that take the value 1 if the country belongs to the corresponding group or zero otherwise. Table 2 lists the countries in each group.

Robust standard errors in round brackets. Regression includes group FE, year FE and group-year FE.

$* * * \mathrm{p}<0.01, * * \mathrm{p}<0.05, * \mathrm{p}<0.1$ 
Table 4: Explaining group membership

\begin{tabular}{|c|c|c|c|c|c|}
\hline & \multirow{2}{*}{$\begin{array}{c}\text { Observed } \\
\text { Frequency }\end{array}$} & $\begin{array}{c}\text { Quality of } \\
\text { institutions }\end{array}$ & $\begin{array}{c}\text { Composition } \\
\text { of public } \\
\text { expenditure }\end{array}$ & $\begin{array}{c}\text { Relative } \\
\text { public and } \\
\text { private } \\
\text { indebtedness }\end{array}$ & Debt maturity \\
\cline { 3 - 6 } & 3.41 & 5.23 & 3.40 & 3.39 & 3.39 \\
\hline Group 1 & 6.03 & 4.62 & 6.03 & 6.06 & 6.03 \\
\hline Group 2 & 13.79 & 12.58 & 13.77 & 13.81 & 13.77 \\
\hline Group 3 & 5.18 & 6.48 & 5.12 & 5.19 & 5.12 \\
\hline Group 4 & 34.49 & 41.94 & 34.62 & 34.49 & 34.63 \\
\hline Group 5 & 10.34 & 10.77 & 10.33 & 10.33 & 10.32 \\
\hline Group 6 & 26.76 & 17.72 & 26.73 & 26.73 & 26.74 \\
\hline Group 7 & & & & \\
\hline
\end{tabular}

Note:

The table reports the observed frequency and the predicted frequencies generated by multinomial logit regression using the different set of independent variables: second column uses a government quality indicator $(G Q I)$; third column uses expenditure on general public services (GF01); expenditure on defence (GF02); expenditure on public order and safety (GF03); expenditure on economic affairs (GF04); expenditure on environment protection (GF05); expenditure on housing and community amenities (GF06); expenditure on health (GF07); expenditure on recreation, culture and religion (GF08); expenditure on education (GF09); and expenditure on social protection (GF010); fourth column uses relative public and private indebtedness ( $D Q P D$ and $D Q P R D$, respectively); and the final column uses a proxy the short-term debt (STD).

See Table 3 for the list of countries belonging to each group. 
Table 5: Exploring drivers of time-varying coefficients by groups

\begin{tabular}{|c|c|c|c|c|c|c|c|}
\hline & Group 1 & Group 2 & Group 3 & Group 4 & Group 5 & Group 6 & Group 7 \\
\hline GQI & $\begin{array}{l}0.0629 \\
(3.2214)\end{array}$ & $\begin{array}{l}5.9607 * * \\
(2.7343)\end{array}$ & $\begin{array}{l}1.4718 * * \\
(0.6814)\end{array}$ & $\begin{array}{l}0.3112 \\
(0.4932)\end{array}$ & $\begin{array}{l}0.6206 * * \\
(0.2758)\end{array}$ & $\begin{array}{l}0.7374 * * * \\
(0.2269)\end{array}$ & $\begin{array}{l}0.9234 * * \\
(0.4312)\end{array}$ \\
\hline DQPD & $\begin{array}{l}-0.2021 * \\
(0.1135)\end{array}$ & $\begin{array}{l}-1.1454 * * \\
(0.5206)\end{array}$ & $\begin{array}{l}-0.5845 \\
(1.0486)\end{array}$ & $\begin{array}{l}-0.5072 \\
(0.3503)\end{array}$ & $\begin{array}{l}-0.4727 * * \\
(0.2055)\end{array}$ & $\begin{array}{l}-1.1531 * * * \\
(0.3631)\end{array}$ & $\begin{array}{l}-0.0183 \\
(0.4658)\end{array}$ \\
\hline DQPRD & $\begin{array}{l}-0.3127 \\
(0.7802)\end{array}$ & $\begin{array}{l}-2.1802^{* *} \\
(0.9955)\end{array}$ & $\begin{array}{l}-0.5880 \\
(0.4827)\end{array}$ & $\begin{array}{l}-0.6903 \\
(1.2634)\end{array}$ & $\begin{array}{l}-0.1201 * * \\
(0.0529)\end{array}$ & $\begin{array}{l}-1.6800 \\
(1.1079)\end{array}$ & $\begin{array}{l}-0.4812 \\
(0.3436)\end{array}$ \\
\hline GF01 & $\begin{array}{l}-1.0025^{* *} \\
(0.4516)\end{array}$ & $\begin{array}{l}-0.5533^{* *} \\
(0.2586)\end{array}$ & $\begin{array}{l}-0.9937 \\
(0.7920) \\
\end{array}$ & $\begin{array}{l}-0.3437 \\
(0.4127) \\
\end{array}$ & $\begin{array}{l}-0.4155^{* * * *} \\
(0.1323)\end{array}$ & $\begin{array}{l}-0.5382 \\
(05174) \\
\end{array}$ & $\begin{array}{l}-0.0629 * * \\
(0.0294)\end{array}$ \\
\hline GF02 & $\begin{array}{l}-0.7625 \\
(0.6333) \\
\end{array}$ & $\begin{array}{l}-2.2672 \\
(2.2278) \\
\end{array}$ & $\begin{array}{l}-0.9030 \\
(0.6231) \\
\end{array}$ & $\begin{array}{l}-0.3434 \\
(0.4263) \\
\end{array}$ & $\begin{array}{l}-0.2844 \\
(0.5974) \\
\end{array}$ & $\begin{array}{l}-1.5507 \\
(4.9610) \\
\end{array}$ & $\begin{array}{l}-0.5223 * * \\
(0.2396) \\
\end{array}$ \\
\hline GF03 & $\begin{array}{l}0.6838 \\
(0.8313) \\
\end{array}$ & $\begin{array}{l}2.3398 \\
(1.7400) \\
\end{array}$ & $\begin{array}{l}0.9353 * * * \\
(0.2960) \\
\end{array}$ & $\begin{array}{l}-0.3180 \\
(0.9615) \\
\end{array}$ & $\begin{array}{l}0.4865 * * * \\
(0.1484) \\
\end{array}$ & $\begin{array}{l}0.5233 \\
(0.7981) \\
\end{array}$ & $\begin{array}{l}0.2421 \\
(0.3396) \\
\end{array}$ \\
\hline GF04 & $\begin{array}{l}0.1472 * * \\
(0.0660)\end{array}$ & $\begin{array}{l}0.4156 \\
(0.7592) \\
\end{array}$ & $\begin{array}{l}0.1894 * * * \\
(0.0608)\end{array}$ & $\begin{array}{l}0.0484 \\
(0.1613) \\
\end{array}$ & $\begin{array}{l}0.0436 * * * \\
(0.0141)\end{array}$ & $\begin{array}{l}0.9651 * * * \\
(0.2797)\end{array}$ & $\begin{array}{l}0.7772 * * \\
(0.3533)\end{array}$ \\
\hline GF05 & $\begin{array}{l}0.1481 * * * \\
(0.0467)\end{array}$ & $\begin{array}{l}0.1161 \\
(0.6504)\end{array}$ & $\begin{array}{l}0.1549 \\
(1.1355)\end{array}$ & $\begin{array}{l}0.3036 \\
(0.3014)\end{array}$ & $\begin{array}{l}0.2130 \\
(0.3450)\end{array}$ & $\begin{array}{l}0.0652 * * * \\
(0.0188)\end{array}$ & $\begin{array}{l}0.2400 * * * \\
(0.0755)\end{array}$ \\
\hline GF06 & $\begin{array}{l}0.2010 \\
(0.5710)\end{array}$ & $\begin{array}{l}0.5610 * * * \\
(0.1645)\end{array}$ & $\begin{array}{l}0.7055 \\
(0.7102)\end{array}$ & $\begin{array}{l}0.2368 \\
(0.4750)\end{array}$ & $\begin{array}{l}0.3957 \\
(1.0877)\end{array}$ & $\begin{array}{l}0.8469 * * \\
(0.3884)\end{array}$ & $\begin{array}{l}0.3440 \\
(0.3678)\end{array}$ \\
\hline GF07 & $\begin{array}{l}0.3868^{* *} \\
(0.1719)\end{array}$ & $\begin{array}{l}0.3300 \\
(0.8984)\end{array}$ & $\begin{array}{l}0.5767 \\
(1.3004)\end{array}$ & $\begin{array}{l}0.9875 * * \\
(0.4631)\end{array}$ & $\begin{array}{l}0.0854 \\
(0.3647)\end{array}$ & $\begin{array}{l}0.0863 \\
(0.5086)\end{array}$ & $\begin{array}{l}0.6741 \\
(0.8329)\end{array}$ \\
\hline GF08 & $\begin{array}{l}-1.10329 * * * \\
(0.3415)\end{array}$ & $\begin{array}{l}-0.3509 \\
(1.2218)\end{array}$ & $\begin{array}{l}-0.3831 * * \\
(0.1821) \\
\end{array}$ & $\begin{array}{l}-1.0951^{* * * *} \\
(0.4081)\end{array}$ & $\begin{array}{l}-0.6840 * * \\
(0.3095)\end{array}$ & $\begin{array}{l}-5.1393 * * * \\
(1.4080)\end{array}$ & $\begin{array}{l}-0.7481 \\
(0.8070) \\
\end{array}$ \\
\hline GF09 & $\begin{array}{l}1.8264 * * * \\
(0.5854)\end{array}$ & $\begin{array}{l}0.2727 * * \\
(0.1151)\end{array}$ & $\begin{array}{l}0.4180 \\
(0.7344)\end{array}$ & $\begin{array}{l}0.2655 \\
(0.4506)\end{array}$ & $\begin{array}{l}0.0973 * * \\
(0.0447)\end{array}$ & $\begin{array}{l}0.7887 * * \\
(0.3585)\end{array}$ & $\begin{array}{l}0.2121 * * * \\
(0.0682)\end{array}$ \\
\hline GF010 & $\begin{array}{l}1.0632 * * \\
(0.4968)\end{array}$ & $\begin{array}{l}4.7131 * * * \\
(1.5204)\end{array}$ & $\begin{array}{l}1.1983 * * * \\
(0.4996)\end{array}$ & $\begin{array}{l}0.4091 * * \\
(0.1853) \\
\end{array}$ & $\begin{array}{l}1.0266 \\
(0.6267) \\
\end{array}$ & $\begin{array}{l}1.2388 * * * \\
(0.3570)\end{array}$ & $\begin{array}{l}0.6746 * * * \\
(0.2213) \\
\end{array}$ \\
\hline STD & $\begin{array}{l}-1.2967 * * * \\
(0.4027)\end{array}$ & $\begin{array}{l}-0.8266 * * \\
(0.3723)\end{array}$ & $\begin{array}{l}-1.4838^{* *} \\
(0.6901)\end{array}$ & $\begin{array}{l}-5.7101 * * * \\
(2.2687)\end{array}$ & $\begin{array}{l}-0.1532^{* * * *} \\
(0.0483)\end{array}$ & $\begin{array}{l}-0.3310 * * * \\
(0.1006)\end{array}$ & $\begin{array}{l}-0.0854 * * * \\
(0.0276)\end{array}$ \\
\hline Constant & $\begin{array}{l}-0.5777 * * \\
(0.2697)\end{array}$ & $\begin{array}{l}-1.1810 * * * \\
(0.3650)\end{array}$ & $\begin{array}{l}-0.6644 * * * \\
(0.2741)\end{array}$ & $\begin{array}{l}-0.4775^{* *} \\
(0.2211)\end{array}$ & $\begin{array}{l}-0.0 .2811 * * * \\
(0.0940)\end{array}$ & $\begin{array}{l}-3.6936 * * \\
(1.6563)\end{array}$ & $\begin{array}{l}-0.2609 * * * \\
(0.0803)\end{array}$ \\
\hline Adjusted $\mathbf{R}^{2}$ & 0.6782 & 0.6735 & 0.6888 & 0.6145 & 0.6410 & 0.6964 & 0.6687 \\
\hline RMSE & 2.1813 & 2.646 & 1.8470 & 4.1703 & 3.9491 & 3.7511 & 3.4540 \\
\hline
\end{tabular}


Notes:

The table reports estimated coefficients from a regression of the time-varying slopes by groups depicted in Figure 3 on its postulated determinants. GOI is a government quality indicator; $D O P D$ and

$D Q P R D$ are relative public and private indebtedness, respectively; GF01 denotes expenditure on general public services; GF02 denotes expenditure on defence; GF03 denotes expenditure on public order and safety; GF04 denotes expenditure on economic affairs; GF05 denotes expenditure on environment protection; GF06 denotes expenditure on housing and community amenities; GF07 denotes expenditure on health; GF08 denotes expenditure on recreation, culture and religion; GF09 denotes expenditure on education; GF10 denotes expenditure on social protection; and STD is a proxy the short-term debt.

See Table 3 for the list of countries belonging to each group.

Robust standard errors in round brackets. ${ }^{* *} \mathrm{p}<0.01,{ }^{* *} \mathrm{p}<0.05,{ }^{*} \mathrm{p}<0.1$. The bold letters show the statistically significant coefficients. 